\title{
Petrogenesis of middle Okinawa Trough volcanic rocks: Constraints from lead isotopes in olivine-hosted melt inclusions
}

\author{
Xiaohui Li ${ }^{\mathrm{a}, \mathrm{b}, \mathrm{c}, *}$, Zhongyuan Ren ${ }^{\mathrm{d}}$, Zhigang Zeng ${ }^{\mathrm{a}, \mathrm{b}, \mathrm{c}, \mathrm{e}, * *}$, Huixin Yang ${ }^{\mathrm{a}}$, Le Zhang ${ }^{\mathrm{d}}$, \\ Xiaoyuan Wang ${ }^{\mathrm{a}, \mathrm{b}, \mathrm{c}}$, Bowen Fang ${ }^{\mathrm{f}}$, Kun Guo ${ }^{\mathrm{g}}$ \\ ${ }^{a}$ Key Laboratory of Marine Geology and Environment, Institute of Oceanology, Chinese Academy of Sciences, Qingdao 266071, China \\ ${ }^{\mathrm{b}}$ Laboratory for Marine Mineral Resources, Qingdao National Laboratory for Marine Science and Technology, Qingdao 266061, China \\ ${ }^{\mathrm{c}}$ Center for Ocean Mega-Science, Chinese Academy of Sciences, Qingdao 266071, China \\ ${ }^{\mathrm{d}}$ State Key Laboratory of Isotope Geochemistry, Guangzhou Institute of Geochemistry, Chinese Academy of Sciences, Guangzhou 510640, China \\ ${ }^{\mathrm{e}}$ University of Chinese Academy of Sciences, Beijing 100049, China \\ ${ }^{\mathrm{f}}$ Research School of Earth Sciences, The Australian National University, Canberra, ACT 2601, Australia \\ ${ }^{\mathrm{g}}$ Center for Isotope Geochemistry and Geochronology, Qingdao National Laboratory for Marine Science and Technology, Qingdao 266237, China
}

\section{A R T I C L E I N F O}

Editor: Catherine Chauvel

Keywords:

Melt inclusions

$\mathrm{Pb}$ isotopes

Petrogenesis

Slab subduction

Okinawa Trough

\begin{abstract}
A B S T R A C T
Olivine-hosted melt inclusions provide crucial information about their parental magma composition and evolution and represent ideal targets for determining the nature of the poorly understood and still-debated magma sources in the Okinawa Trough, a back-arc basin in the western Pacific. We present the first analyses of the lead $(\mathrm{Pb})$ isotope compositions of olivine-hosted melt inclusions to evaluate the mantle properties and petrogenesis of middle Okinawa Trough volcanic rocks. The melt inclusions have more variable major and trace elements and $\mathrm{Pb}$ isotope compositions than the host whole-rock samples. We report the discovery of both high- ${ }^{207} \mathrm{~Pb} /{ }^{206} \mathrm{~Pb}$ $(>0.865)$ and low- ${ }^{207} \mathrm{~Pb} /{ }^{206} \mathrm{~Pb}(<0.865)$ isotope compositions in melt inclusions in individual volcanic rocks, even within a single host olivine, indicating a compositionally heterogeneous magma source. The trace element and $\mathrm{Pb}$ isotope characteristics of the melt inclusions show that the magma source is affected by enriched components. We modeled the injection of enriched components into a magma source to explain the generation of the magma heterogeneity. The results indicate that the mixing of Pacific Ocean-type mantle (MORB), an EMI-like component from recycled lower continental crust and EMII-like material from subducted sediments can explain the low- ${ }^{207} \mathrm{~Pb} /{ }^{206} \mathrm{~Pb}$ isotope values observed in the melt inclusions. The discovery of small proportions of melt inclusions with high ${ }^{207} \mathrm{~Pb} /{ }^{206} \mathrm{~Pb}$ ratios, high $\mathrm{K}_{2} \mathrm{O}, \mathrm{P}_{2} \mathrm{O}_{5}, \mathrm{Rb}$ and $\mathrm{U}$ contents and low $\mathrm{Pb}$ and $\mathrm{Cu}$ contents in the studied andesites suggests that the andesitic magma may have been formed by the mixing of materials with different elemental and isotopic compositions. Our study results suggest that pervasive magma mixing may have occurred in the magma source prior to eruption in the Okinawa Trough.
\end{abstract}

\section{Introduction}

Assessing the petrogenesis of volcanic rocks in subduction zone settings is important but is also complicated by many different processes, such as fractional crystallization, magma mixing and crustal assimilation, and by geochemical variations in the source components, such as the mantle wedge, subducted oceanic crust and accompanying sediments or melts; these processes and sources exert control over the geochemistry of volcanic rocks (e.g., Hawkesworth et al., 1991;
McCulloch and Gamble, 1991; Pearce and Peate, 1995) and can result in heterogeneity in the Earth's mantle (Hofmann, 1997; Saal et al., 1998; Pilet et al., 2011). Back-arc basins are important part of subduction zones and can reflect magmatism during slab subduction. Compared with intra-oceanic back-arc basins (e.g., the Mariana trough, Manus basin, Lau basin and North Fiji basin), epicontinental back-arc basins may be affected by the continental crust, and the resulting magmatic characteristics are more complex (Shinjo, 1999). Therefore, investigating magmatic activity in epicontinental back-arc basins is

\footnotetext{
*Correspondence to: Xiaohui Li, Key Laboratory of Marine Geology and Environment, Institute of Oceanology, Chinese Academy of Sciences, Qingdao 266071, China.

** Correspondence to: Zhigang Zeng, Key Laboratory of Marine Geology and Environment, Institute of Oceanology, Chinese Academy of Sciences, Qingdao 266071, China.

E-mail addresses: lixiaohui@qdio.ac.cn (X. Li), zgzeng@qdio.ac.cn (Z. Zeng).
} 
conducive to fully understanding subduction-zone magmatism.

The Okinawa Trough, which was formed by the subduction of the Philippine Sea Plate, is a young and actively spreading epicontinental back-arc basin located in the western Pacific (Shinjo, 1999) and is an ideal location in which to study mantle-crust interactions and the genesis of volcanic rocks in a subduction zone setting (e.g., Ishizuka et al., 1990; Honma et al., 1991; Shinjo, 1999; Shinjo et al., 1999; Shinjo and Kato, 2000; Hoang and Uto, 2006; Zeng et al., 2010; Guo et al., 2016a, 2016b; Yu et al., 2016; Shu et al., 2017; Chen et al., 2018; Zhang et al., 2018; Li et al., 2018a, 2018b, 2019). Previous studies have shown that the magma source of the Okinawa Trough is affected by the subductions of the Philippine Sea Plate (Shinjo, 1999), but the subduction components and mantle sources remain controversial (Yan and Shi, 2014). Indeed, the following possible origins have been proposed: (1) the magma may be generated by interactions between enriched midocean ridge basalt (E-MORB)-like mantle and a subducted component (Shinjo, 1999); (2) the magma may be transitional between a Ryukyu island arc-type magma and a normal MORB (N-MORB)-like magma (Ishizuka et al., 1990); (3) the magma may be produced by the interaction between Indian Ocean-type mantle and continental lithosphere (Zeng et al., 2010); or (4) the magma may originate from a mixture of Pacific MORB-like mantle with an enriched mantle type II (EMII) component (Hoang and Uto, 2006). In addition, the identification of magma evolution processes, such as fractional crystallization (Shinjo, 1999), magma mixing (Ishizuka et al., 1990), assimilation and fractional crystallization (AFC) (Shinjo and Kato, 2000; Zhang et al., 2018) and crustal contamination (Guo et al., 2016; Chen et al., 2018), is also controversial in the Okinawa Trough.

Generally, the significant contrast between the $\mathrm{Pb}$ concentrations and isotope compositions of the mantle and those of marine and sediments (e.g., Gasparon and Varne, 1998; Chauvel and Blichert-Toft, 2001) indicates that the $\mathrm{Pb}$ isotope ratios of mantle-derived magma are highly sensitive to the addition of subduction-related material during the petrogenesis of volcanic rocks (e.g., Miller et al., 1994; Carpentier et al., 2008). However, surprisingly few published $\mathrm{Pb}$ isotope data are available for Okinawa Trough volcanic rocks, and all of these rocks plot in the Indian Ocean-type mantle field (Hoang and Uto, 2006; Guo et al., 2016; Shu et al., 2017; Li et al., 2018; Zhang et al., 2018), even though the corresponding samples were collected in the Pacific Ocean. In addition, most previous studies in this region were based on whole-rock data, and the chemical and isotopic signatures of magma sources can be obscured due to complex petrogenesis involving fractional crystallization, magma mixing and crustal assimilation (e.g., Sobolev, 1996; Ren et al., 2005); thus, whole-rock compositions cannot be effectively used to represent the parental magma compositions and reveal magma evolution processes. Melt inclusions are small magma droplets trapped in phenocrysts during crystallization (Sorby, 1858; Roedder, 1979), in which the trapped melt has been minimally modified by magma processes, such as assimilation, contamination or degassing processes (Zajacz and Halter, 2007; Ren et al., 2017). Therefore, melt inclusions have proven to be a valuable tool for defining the compositions of preaggregated melts and assessing the petrogenesis of volcanic rocks, which may not always be identifiable through the analysis of wholerock samples (e.g., Saal et al., 1998; Sobolev et al., 2000; Ren et al., 2005, 2017; Kamenetsky et al., 2006, 2012).

In this paper, we present the first analyses of the $\mathrm{Pb}$ isotope compositions of olivine-hosted melt inclusions obtained from middle Okinawa Trough volcanic rocks. The results of this work provide new insights into the geochemical compositions of the magma and demonstrate that these melt inclusions are crucial for testing the petrogenesis of volcanic rocks from the Okinawa Trough.

\section{Geological background}

The Okinawa Trough is located on the southeastern side of the East China Sea (Fig. 1), where the Philippine Sea Plate is subducting beneath the Eurasian Plate, forming a back-arc basin in the Ryukyu basin-arctrench system (Shinjo, 1999). Based on its tectonic characteristics, the Okinawa Trough can be divided into three segments, i.e., the northern Okinawa Trough, middle Okinawa Trough and southern Okinawa Trough, which are separated successively by the Tokara fault and the Kerama gap (Shinjo, 1999). At present, the northern segment is experiencing crustal extension, the middle segment is undergoing propagating rift processes, and the southern segment is showing signs of initial spreading (Yan and Shi, 2014). The Okinawa Trough has experienced intense magmatic activity, which has generated abundant volcanic rocks (Shinjo et al., 1999). The northern Okinawa Trough is dominated by rhyolites (e.g., Zeng et al., 2010), and the southern Okinawa Trough is dominated by basaltic rocks (e.g., Shinjo et al., 1999). The middle Okinawa Trough volcanic rocks exhibit bimodal characteristics, forming a basaltic-rhyolitic suite containing a relatively small quantity of andesite (e.g., Shinjo and Kato, 2000). These three segments have different crustal thicknesses of 15-23 km in the northern segment, $12-18 \mathrm{~km}$ in the middle segment, and $10-16 \mathrm{~km}$ in the southern segment (Sibuet et al., 1995; Liu et al., 2016). From north to south, the subduction rate of the Philippine Sea Plate increases from 4.9 to $7.3 \mathrm{~cm} / \mathrm{yr}$ (Shinjo, 1999), and the extension rate also increases from $2 \mathrm{~cm} / \mathrm{yr}$ to $5 \mathrm{~cm} / \mathrm{yr}$ (Arai et al., 2017).

\section{Samples and analytical methods}

\subsection{Sample descriptions}

The volcanic samples used in this study were recovered using a TVgrab sampler during the R/V Kexue HOBAB 2 cruise in 2014 and the HOBAB 4 cruise in 2016 (Fig. 1). One basalt sample (R2, $27^{\circ} 32^{\prime} 28.214^{\prime \prime} \mathrm{N}, 126^{\circ} 58^{\prime} 37.281^{\prime \prime} \mathrm{E}, 1309.7 \mathrm{~m}$ ) and two andesite samples (T5-2, $27^{\circ} 32^{\prime} 51.767^{\prime \prime} \mathrm{N}, 126^{\circ} 59^{\prime} 21.669^{\prime \prime} \mathrm{E}, 1283 \mathrm{~m}$ ) were collected from the middle Okinawa Trough, and whole-rock and olivine-clinopyroxene analyses show that they are congenetic (Li et al., 2018, 2020a, 2020b) (Fig. 1). The detailed petrography of these samples has been described in our previous studies (Li et al., 2018a, 2018b, 2019). In terms of geochemical characteristics, all of the whole-rock samples are subalkaline and enriched in large-ion lithophile elements (LILEs) relative to the high field strength elements (HFSEs) and rare earth elements (REEs), with obvious positive $\mathrm{Pb}$ and $\mathrm{K}$ anomalies and negative Nb, Ta and Ti anomalies (Li et al., 2018a, 2018b, 2019) (Fig. 2a, b). The Sr-Nd isotope compositions of the whole-rock samples show that the magma source may have been affected by a subducted sediment component (Honma et al., 1991; Shinjo et al., 1999; Guo et al., 2016; Li et al., 2018) (Fig. 2c). All of the samples collected in this study are phyric, and olivine, plagioclase and pyroxene are the main phenocryst minerals (Fig. 3a, b). The olivine phenocrysts in all samples are euhedral to subhedral and contain abundant melt inclusions that are round or elliptical in shape, $30-80 \mu \mathrm{m}$ in size and distributed randomly within the olivine (Figs. $3 \mathrm{c}, \mathrm{d}$ and $\mathrm{S} 1$ ).

\subsection{Analytical methods}

\subsubsection{Major element analysis}

The preparation of melt inclusions was performed at the melt inclusion laboratory in the State Key Laboratory of Isotope Geochemistry, Guangzhou Institute of Geochemistry, Chinese Academy of Sciences (GIGCAS). Photomicrographs under both transmitted and reflected light were used to select unaltered melt inclusion-bearing olivine phenocrysts for elemental and isotopic analysis. The melt inclusions, which were affected by significant post-entrapment crystallization (Fig. 3d), were homogenized in this study following the procedure in Ren et al. (2005, 2017): A $1 \mathrm{~atm}$ gas mixing furnace was used, and the oxygen fugacity was kept at the quartz-fayalite-magnetite (QFM) buffer using a $\mathrm{CO}_{2}-\mathrm{H}_{2}$ gas mixture in the furnace. A platinum packet containing host olivine crystals was heated at a constant temperature $\left(1250{ }^{\circ} \mathrm{C}\right)$ for 


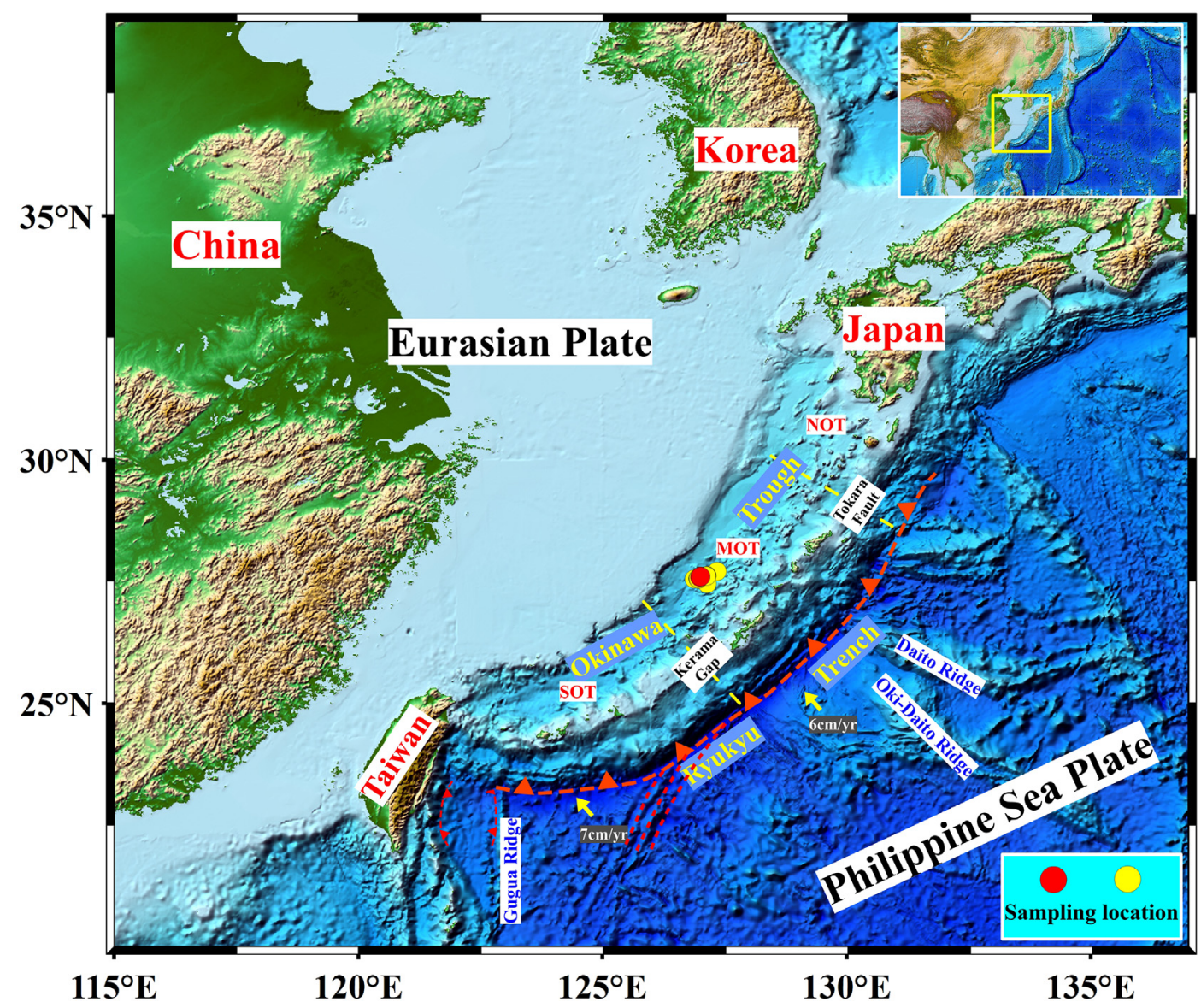

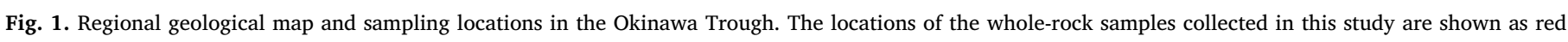

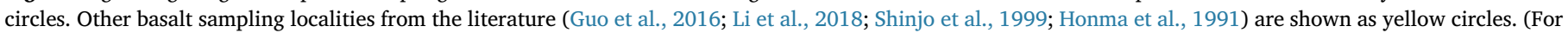
interpretation of the references to colour in this figure legend, the reader is referred to the web version of this article.)

10 min, such that the crystal-glass mixture melted. Then, the packet was quickly raised (within $1 \mathrm{~s}$ ) to the top of the furnace tube to achieve quenching. Some melt inclusions from basalt are glassy inclusions (Figs. $3 \mathrm{c}$ and S1) that are homogeneous and quenched in nature and do not require heating, homogenization, and quenching, so these melt inclusions can be analyzed in their present form (e.g., Streck and Wacaster, 2006; Maclennan, 2008; Hartley et al., 2013). After homogenization, the host olivines were mounted on epoxy resin disks and polished with silicon carbide and diamond powder until the melt inclusions were exposed.

The major element compositions of the melt inclusions and host olivines were analyzed with a JEOL JXA-8230 electron probe microanalyzer (EPMA) at the Key Laboratory of Submarine Geosciences and Prospecting Techniques, Ministry of Education, Ocean University of China, Qingdao. The operating conditions were as follows: the olivine analyses used an accelerating voltage of $20 \mathrm{kV}$, a beam current of $20 \mathrm{nA}$, a beam diameter of $2 \mu \mathrm{m}$, and a peak counting time of $20 \mathrm{~s}$. The melt inclusion analyses used an accelerating voltage of $15 \mathrm{kV}$, a beam current of $20 \mathrm{nA}$ and a beam diameter of $5 \mu \mathrm{m}$. For the melt inclusions, $\mathrm{Na}$ and $\mathrm{K}$ were measured first in each analysis, with $10 \mathrm{~s}$ as the peak counting time and $5 \mathrm{~s}$ as the background counting time. The standards used in these analyses included albite for $\mathrm{Na}, \mathrm{Al}$ and $\mathrm{Si}$; diopside for $\mathrm{Mg}$ and $\mathrm{Ca}$; sanidine for K; rutile for Ti; almandine for Fe; bustamite for Mn and chromium oxide for Cr. The precision was better than $1 \%$ for the major element analyses and better than $5 \%$ for the minor element analyses.

\subsubsection{Trace element analysis}

After the EPMA measurements, the trace elements in the melt inclusions were measured with an ELEMENT XR (Thermo Fisher Scientific) inductively coupled plasma sector field mass spectrometry (ICP-SF-MS) instrument coupled with a 193-nm (ArF) Resonetics RESOlution M-50 laser ablation system at the State Key Laboratory of Isotope Geochemistry, GIGCAS. Prior to this procedure, the carbon coating on each epoxy resin disk was removed completely by polishing with $0.25 \mu \mathrm{m}$ alumina powder, and each disk was washed with purified $0.1 \%$ nitric acid. The detailed experimental procedure and data-reduction strategy are described in Zhang et al. (2019). The laser conditions were set as follows: $24 \mu \mathrm{m}$ beam size, $\sim 4 \mathrm{~J} \mathrm{~cm}^{-2}$ energy density and $5 \mathrm{~Hz}$ repetition rate. Each spot analysis comprised a $20 \mathrm{~s}$ gas blank collection with the laser off and a $30 \mathrm{~s}$ sample signal detection with the laser on. Measurements were executed under the E scan mode. A smoothing device (The Squid, Laurin Technic) was used to smooth the sample signal. $\mathrm{Si}$, which was pre-measured with the EPMA, was selected as the internal standard element. The calibration line for each element was constructed by analyzing three USGS reference glasses, namely, BHVO-2G, BCR-2G and GSD-1G, from GeoReM (http://georem.mpchmainz.gwdg.de/). The USGS reference glass TB-1G was measured as the unknown sample. Twenty-seven analyses of TB-1G indicated that most elements were within $8 \%$ of the reference values and that the analytical precision (2RSD) was better than $15 \%$ for most trace elements (Table S1).

\subsection{3. $\mathrm{Pb}$ isotope analysis}

Melt inclusions with diameters $>40 \mu \mathrm{m}$ were chosen for in situ $\mathrm{Pb}$ isotope analysis using a Neptune Plus multiple collector inductively coupled plasma mass spectrometer (MC-ICP-MS) with a $193 \mathrm{~nm}$ (ArF) Resonetics RESOlution M-50 laser ablation system in the State Key 

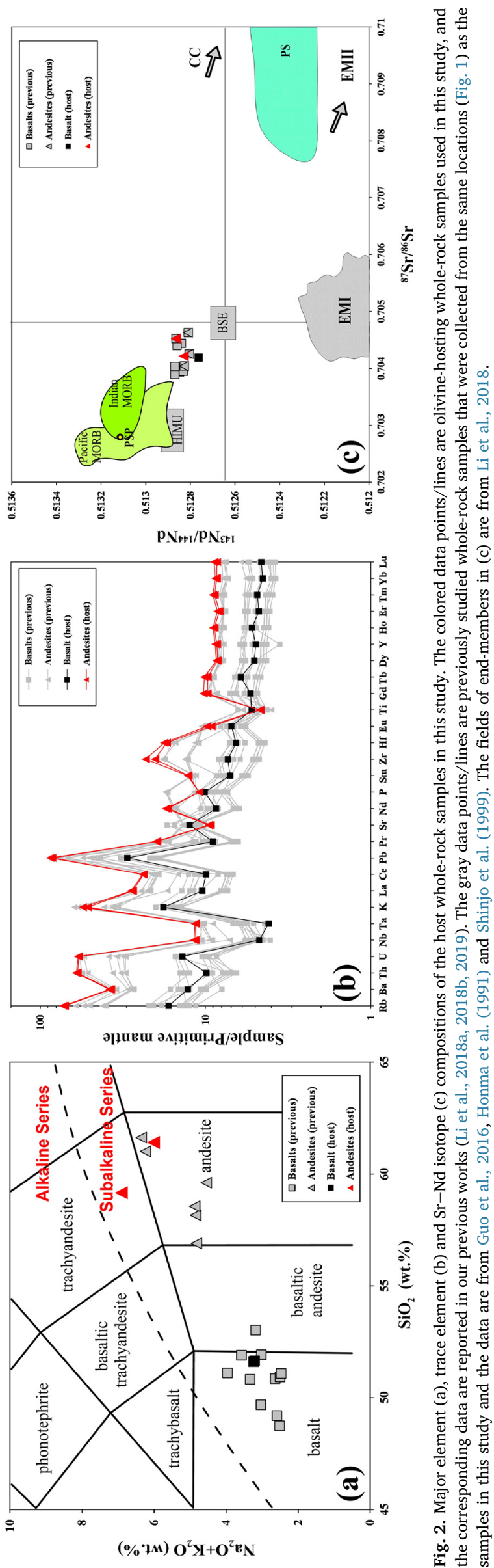

Laboratory of Isotope Geochemistry, GIGCAS. The detailed procedure for the $\mathrm{Pb}$ isotope analysis was previously described by Zhang et al. (2014). The laser parameters were set as follows: a beam diameter of $45 \mu \mathrm{m}$, an energy of $80 \mathrm{~mJ}$, an attenuation value of $25 \%$, a repetition rate of $3 \mathrm{~Hz}$, and an integration time of $0.262 \mathrm{~s}$. An X skimmer cone in the interface and a low flow of $\mathrm{N}_{2}\left(2 \mathrm{ml} \mathrm{L}^{-1}\right)$ were used to improve the instrumental sensitivity. All isotope signals were detected with ion counters under static mode. Helium was chosen as the carrier gas $\left(800 \mathrm{ml} \mathrm{min}^{-1}\right)$. The first $28 \mathrm{~s}$ were used to detect the gas blank with the laser beam off, and the following $30 \mathrm{~s}$ were used to perform laser ablation and collect sample signals with the laser beam on. The international basaltic glass standard NKT-1G (basaltic glass, Elburg et al., 2005) was chosen as the external standard. Before and after each batch of five melt inclusion analyses, a basaltic glass standard BHVO-2G was measured to monitor the instrumental drift. NKT-1G and BHVO-2G were measured repeatedly to evaluate the accuracy of the instrument before each batch analysis. Because of the low relative abundance of ${ }^{204} \mathrm{~Pb}$ and the isobaric interference of ${ }^{204} \mathrm{Hg}$, here, we present only the ${ }^{207} \mathrm{~Pb} /{ }^{206} \mathrm{~Pb}$ and ${ }^{208} \mathrm{~Pb} /{ }^{206} \mathrm{~Pb}$ ratios of the melt inclusions. The analyse of BHVO-2G during the course of this study yielded weighted mean values of ${ }^{208} \mathrm{~Pb} /{ }^{206} \mathrm{~Pb}=2.0545 \pm 0.007$ (2SD, $\left.\mathrm{n}=25\right)$ and ${ }^{207} \mathrm{~Pb} /{ }^{206} \mathrm{~Pb}=0.8332 \pm 0.0032(2 \mathrm{SD}, \mathrm{n}=25)$, which are consistent (within error) with the values reported by Weis et al. (2006) $(2.0524$ and 0.8345 , respectively). The external precisions were better than $0.35 \%$ for ${ }^{208} \mathrm{~Pb} /{ }^{206} \mathrm{~Pb}$ and $0.38 \%$ for ${ }^{207} \mathrm{~Pb} /{ }^{206} \mathrm{~Pb}(2 \mathrm{RSD}, \mathrm{n}=25)$, whereas the accuracies were better than $0.10 \%$ for ${ }^{208} \mathrm{~Pb} /{ }^{206} \mathrm{~Pb}$ and $0.15 \%$ for ${ }^{207} \mathrm{~Pb} /{ }^{206} \mathrm{~Pb}$ (Table S2).

\section{Results}

\subsection{Chemical compositions of the olivine}

The host olivine composition data are provided in Table S3. The host olivines in the basalt yielded values of 76.3-87.3 Fo, 0.17-0.40 wt $\% \mathrm{MnO}$ and $0.07-0.25 \mathrm{wt} \% \mathrm{CaO}$, while in the andesites yielded values of 72.9-83.2 Fo, 0.21-0.42 wt\% MnO and 0.10-0.28 wt\% CaO. Almost all of the olivines from the studied volcanic rocks had $\mathrm{CaO}$ values between $0.1 \mathrm{wt} \%$ and $0.3 \mathrm{wt} \%$, which are higher than the values of typical mantle xenocrysts $(\mathrm{CaO}<0.1 \mathrm{wt} \%$; Cameron, 1985; Kamenetsky et al., 2006; Gavrilenko et al., 2016).

\subsection{Chemical compositions of the melt inclusions}

The compositions of melt inclusions (Table S4) can be changed by crystallization and/or equilibration after entrapment (Danyushevsky et al., 2000, 2002; Kent, 2008). These changes are caused by the crystallization of the host mineral on the inclusion walls or the crystallization of other daughter phases, and such processes have been experimentally reversed by remelting and homogenizing melt inclusions. The compositions of inclusions affected by such processes can be recalculated to be in equilibrium with the host olivine by applying the model of Ford et al. (1983) using PETROLOG software (Danyushevsky and Plechov, 2011). This calculation requires an independent estimate of the initial FeOt content of the trapped melt, which can be obtained using the FeOt fractionation trend exhibited by the whole-rock samples (Danyushevsky et al., 2000, 2002). Due to the small changes in the FeOt content of whole-rock samples in the study area, we used the average iron content to determine the initial FeOt contents of the trapped melts in the melt inclusions, which was $9.66 \mathrm{wt} \%$ in the basalt and andesites.

The major element compositions of the melt inclusions after correction are listed in Table S5 and displayed on the total alkali-silica (TAS) and $\mathrm{SiO}_{2}$ versus $\mathrm{K}_{2} \mathrm{O}$ diagrams (Fig. 4). On the TAS diagram (Fig. 4a), most melt inclusions from the basalt have compositions similar to those of their host whole-rock samples, and they mainly plot near the intersection of the basalt and basaltic andesite fields. The compositions of melt inclusions from the andesites are clearly more 

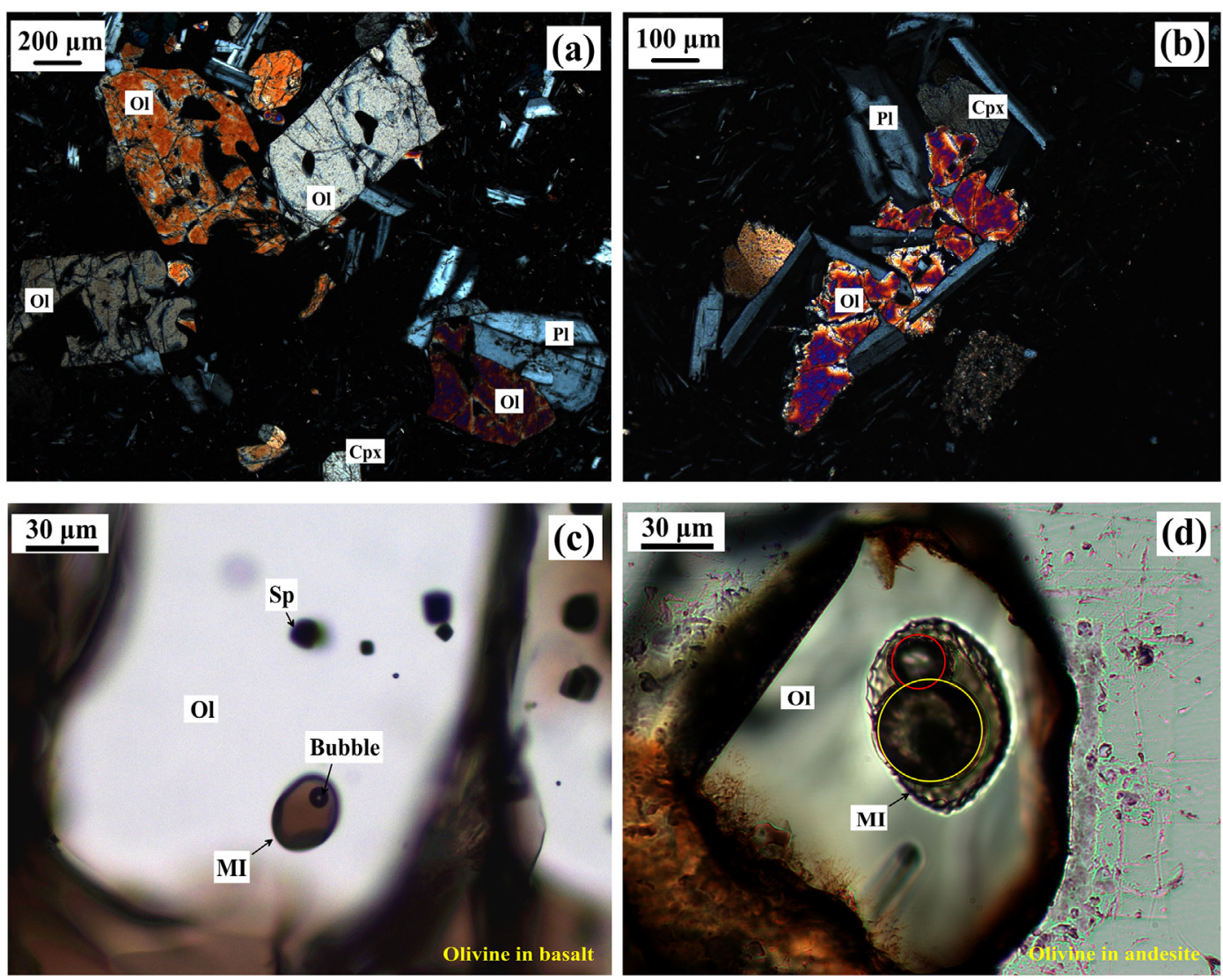

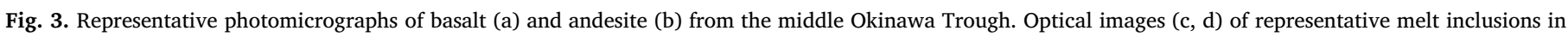

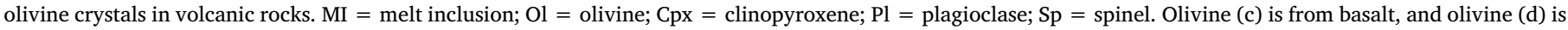

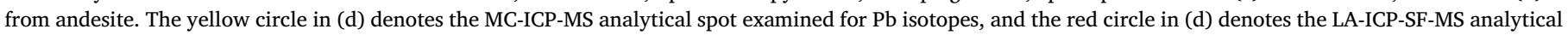
spot examined for trace elements. (For interpretation of the references to colour in this figure legend, the reader is referred to the web version of this article.)

primitive than those of their host whole-rock samples, and they mostly plot in the basalt field, with some plotting in the basaltic andesite and andesite fields. The $\mathrm{SiO}_{2}$ versus $\mathrm{K}_{2} \mathrm{O}$ diagram (Fig. 4b) shows that most melt inclusions in the basalt and andesites belong to the low-K arctholeiitic series and some melt inclusions in andesites belong to the medium-K calc-alkaline series. The $\mathrm{MgO}$ contents of the melt inclusions from the basalt and andesites are 5.53-11.04 wt \% and 4.18-7.92 wt\%, respectively (Table S5; Fig. 5). Some melt inclusions in the andesites have higher $\mathrm{SiO}_{2}$ and $\mathrm{K}_{2} \mathrm{O}$ contents but lower $\mathrm{TiO}_{2}$ and $\mathrm{CaO}$ contents than those of the melt inclusions in the basalt at a given $\mathrm{MgO}$ content
(Fig. 5). In addition, the variations in the major oxide versus $\mathrm{MgO}$ contents of the melt inclusions from the basalt show continuously changing trends that closely resemble the typical evolution of fractional crystallization (e.g., Park et al., 2010). However, considerable scatter exists in the major elemental compositions at a given $\mathrm{MgO}$ content in the melt inclusions from the andesites, with poor correlations observed between $\mathrm{TiO}_{2}\left(\mathrm{Al}_{2} \mathrm{O}_{3}, \mathrm{CaO}\right.$ and $\left.\mathrm{K}_{2} \mathrm{O}\right)$ and $\mathrm{MgO}$ (Fig. 5). The $\mathrm{K}_{2} \mathrm{O}$ contents in melt inclusions from the andesites range from 0.15 to $1.67 \mathrm{wt} \%$, and some melt inclusions are clearly richer in $\mathrm{K}_{2} \mathrm{O}$ than other melt inclusions (Fig. 5e).
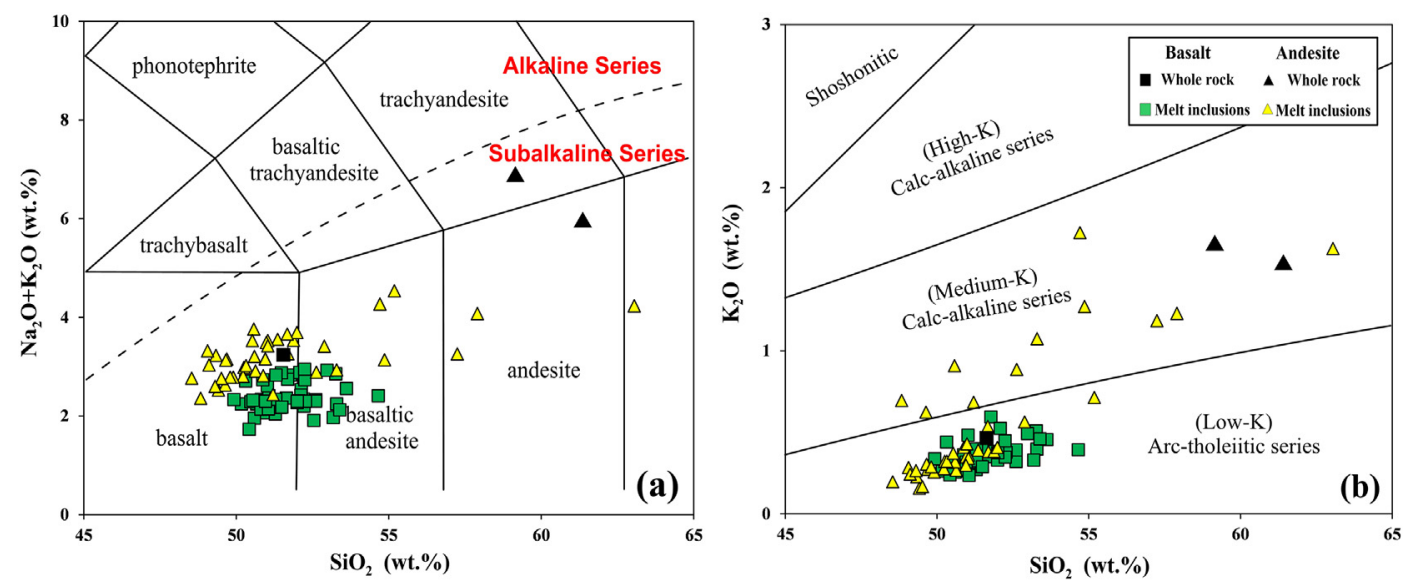

Fig. 4. Plots of the corrected melt inclusions and whole-rock samples on the total alkali-silica classification $\left(\mathrm{Na}_{2} \mathrm{O}+\mathrm{K}_{2} \mathrm{O}\right.$ versus $\left.\mathrm{SiO}_{2}\right)\left(\right.$ a) and $\mathrm{SiO}_{2}$ versus $\mathrm{K}_{2} \mathrm{O}$ (b) diagrams. 


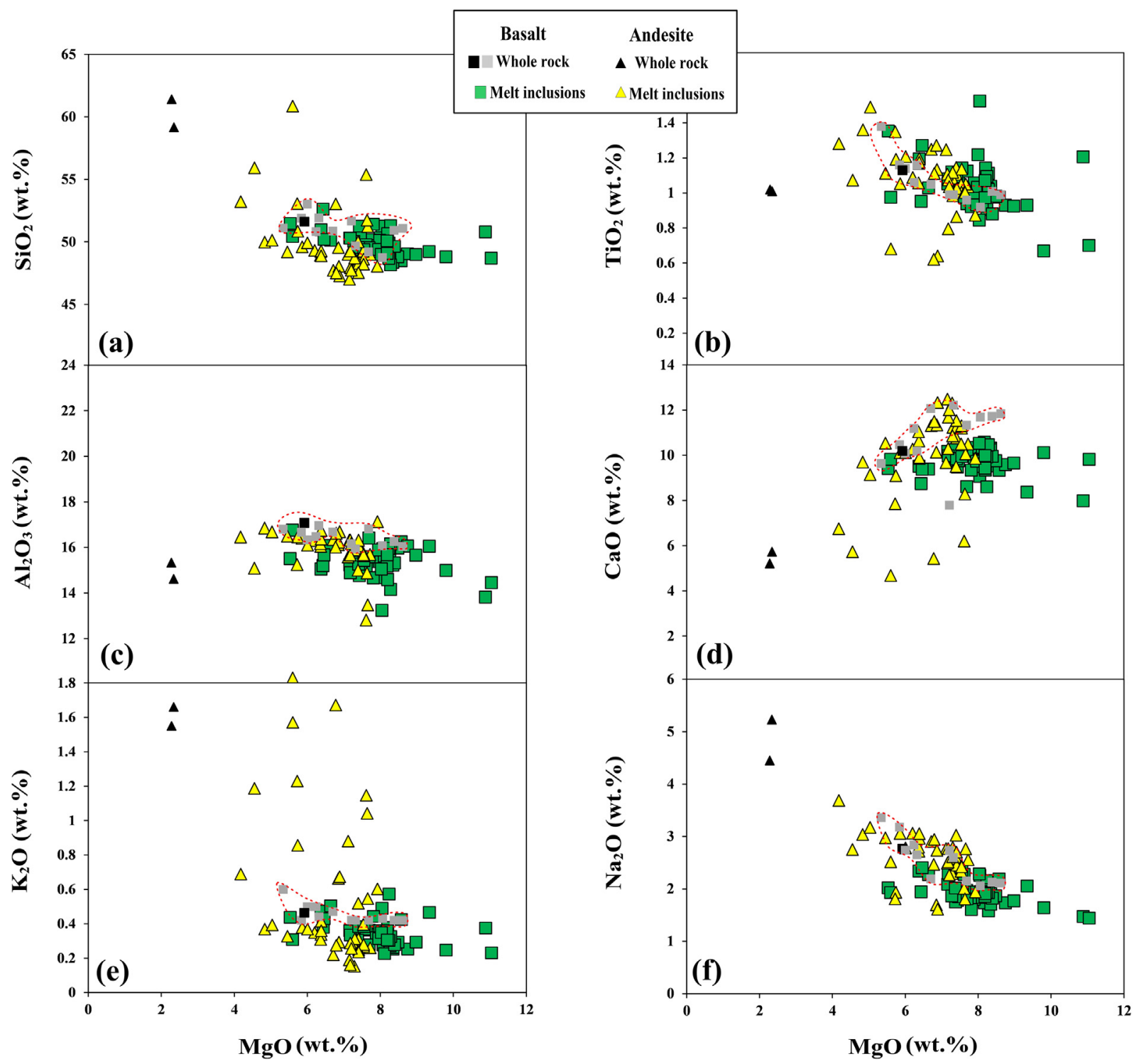

Fig. 5. Variations in $\mathrm{SiO}_{2}, \mathrm{TiO}_{2}, \mathrm{Al}_{2} \mathrm{O}_{3}, \mathrm{CaO}, \mathrm{K}_{2} \mathrm{O}$ and $\mathrm{Na}_{2} \mathrm{O}$ versus $\mathrm{MgO}$ in the whole-rock samples and corrected melt inclusions measured in this study. The symbols used for whole-rock data are the same as those in Fig. 2. The red dashed lines are the range of basaltic whole-rock compositions from the middle Okinawa Trough. (For interpretation of the references to colour in this figure legend, the reader is referred to the web version of this article.)

The major and trace element compositions of the melt inclusions obtained by LA-ICP-SF-MS are listed in Table S6. The major element data are consistent with the data obtained by EPMA (Fig. S2). In the primitive mantle-normalized trace element spider diagrams (Fig. 6), all of the melt inclusions in the studied volcanic rocks are markedly enriched in LILEs relative to HFSEs and slightly depleted in REEs. Notably, there are positive $\mathrm{K}$ and $\mathrm{Sr}$ anomalies and negative $\mathrm{Nb}$ and $\mathrm{Ta}$ anomalies. The trace element distribution patterns of the melt inclusions in the basalt are similar to those of their host whole-rock samples (Fig. 6a), whereas the trace element content levels of the melt inclusions in the andesites are lower than those of their host whole-rock samples (Fig. 6b). Meanwhile, compared with their host whole-rock samples, some melt inclusions in the andesites have clear negative $\mathrm{Pb}$ and positive $\mathrm{P}$ anomalies (Fig. $6 \mathrm{~b}$ ). In addition, the trace element distribution pattern of the melt inclusions in the basalt and most of the melt inclusions in the andesites are similar to that of the lower continental crust, which may suggest that the compositions of the melt inclusions were influenced by some lower continental crust components.

\section{3. $\mathrm{Pb}$ isotope compositions of the melt inclusions}

The newly obtained $\mathrm{Pb}$ isotope data for the melt inclusions are presented in Table S7 and Fig. 7. The ${ }^{207} \mathrm{~Pb} /{ }^{206} \mathrm{~Pb}$ and ${ }^{208} \mathrm{~Pb} /{ }^{206} \mathrm{~Pb}$ values of the melt inclusions in the basalt range from 0.8404 to 0.8515 and from 2.0787 to 2.1104 , with mean values of $0.8464 \pm 0.0048$ (2SD, $\mathrm{n}=26$ ) and $2.0937 \pm 0.0140$ (2SD, $\mathrm{n}=26$ ), respectively. These values are similar to previously reported basaltic whole-rock values in the middle Okinawa Trough $\left({ }^{207} \mathrm{~Pb} /{ }^{206} \mathrm{~Pb}=0.8434\right.$ to 0.8479 and ${ }^{208} \mathrm{~Pb} /{ }^{206} \mathrm{~Pb}=2.0870$ to 2.0988; Hoang and Uto, 2006; Shu et al., 2017; Li et al., 2018), and most plot in the Indian Ocean-type mantle field (Fig. 7). The ${ }^{207} \mathrm{~Pb} /{ }^{206} \mathrm{~Pb}$ and ${ }^{208} \mathrm{~Pb} /{ }^{206} \mathrm{~Pb}$ ratios of the melt inclusions from the andesites range from 0.8437 to 0.8798 and from 2.0834 to 2.1438 , respectively (Fig. 7). These ranges of $\mathrm{Pb}$ isotope values are much larger than those previously reported for whole-rock samples in this area. Obviously, the Pb isotope compositions of the melt inclusions in the andesites vary significantly and can be divided into two groups: the majority of melt inclusions with low ${ }^{207} \mathrm{~Pb} /{ }^{206} \mathrm{~Pb}$ $(<0.865)$ fall around the field defined by the melt inclusions in basalt, but those with high ${ }^{207} \mathrm{~Pb} /{ }^{206} \mathrm{~Pb}(>0.865)$ deviate slightly from the 

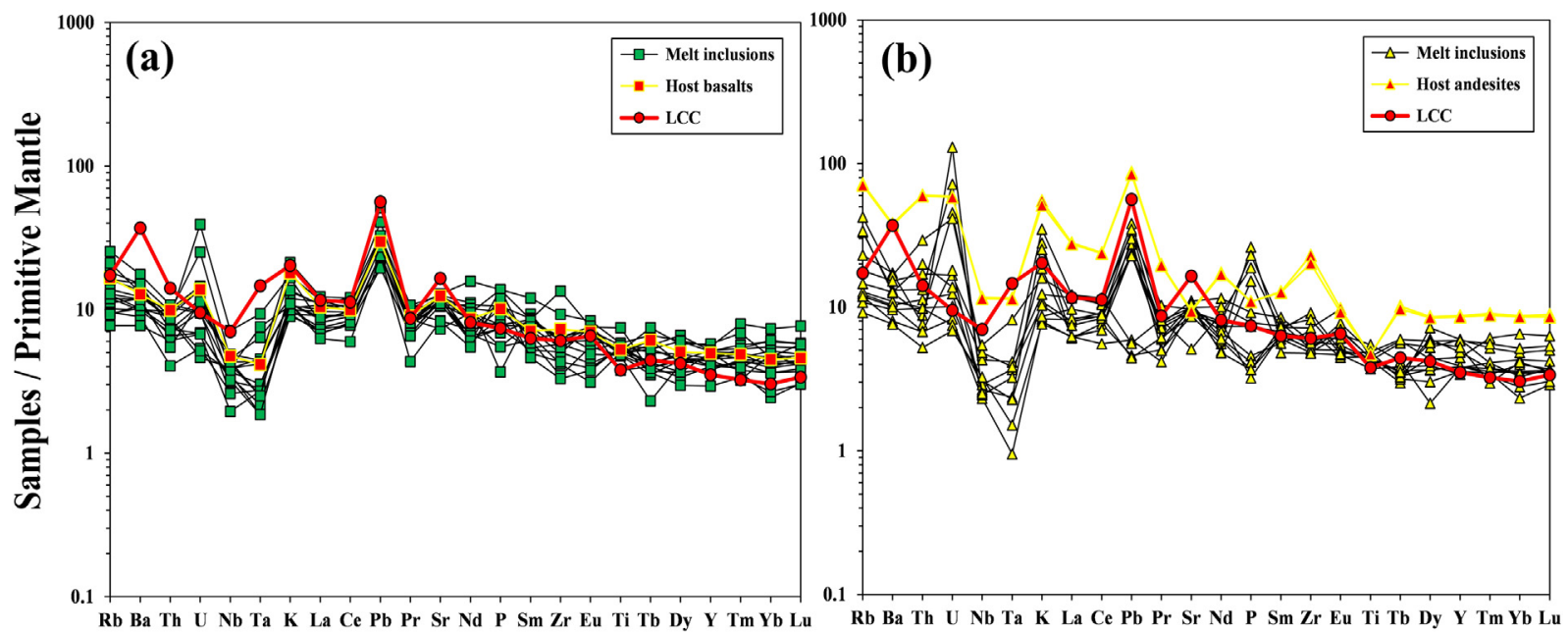

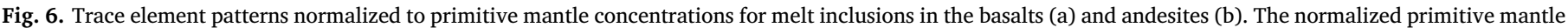

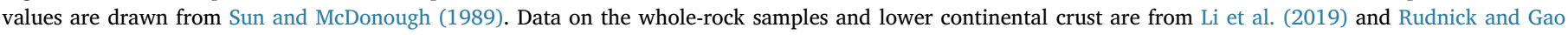
(2003), respectively.

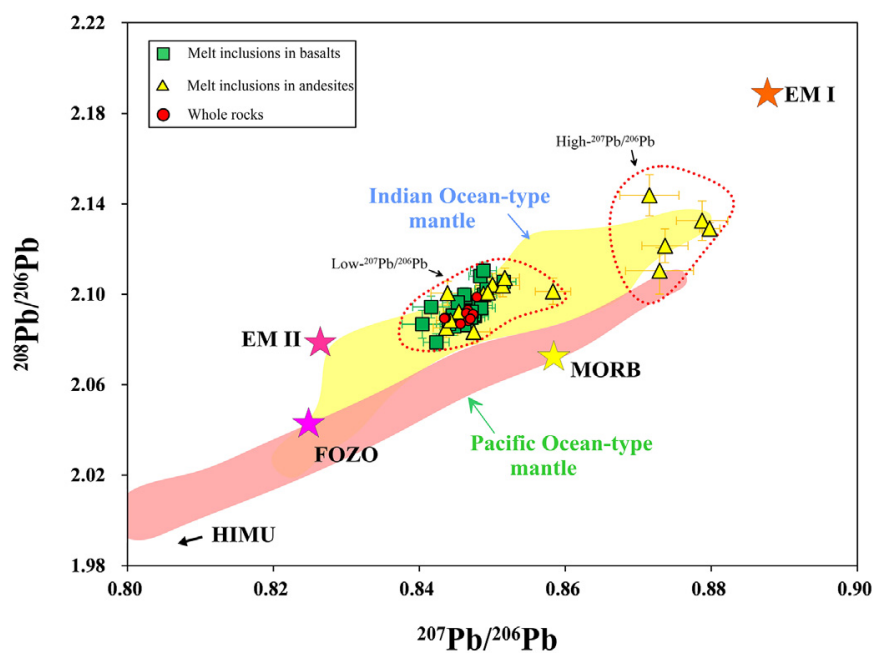

Fig. 7. $\mathrm{Pb}$ isotope ratios of melt inclusions and whole-rock samples from the middle Okinawa Trough, together with the fields of Indian Ocean-type and Pacific Ocean-type mantle. Data sources: Whole-rock data are from Hoang and Uto (2006), Shu et al. (2017), Guo et al. (2016), Zhang et al. (2018) and Li et al. (2018). The EMI, EMII and MORB end-member data are from Saal et al. (1998, 2005). Data for Indian Ocean-type mantle are from Cohen et al. (1980), Sun (1980), Cohen and O'Nions (1982), Dupre and Allegre (1983), Price et al. (1986), Ito et al. (1987), Dosso et al. (1988) and Mahoney et al. (1989). Pacific Ocean-type mantle data are from Cohen et al. (1980), Cohen and O'Nions (1982), Church and Tatsumoto (1975), Ito et al. (1987), Tatsumoto (1978), Hamelin et al. (1984), White et al. (1987), Hanan and Schilling (1989) and Mahoney et al. (1994).

$\mathrm{Pb}-\mathrm{Pb}$ isotope arrays toward enriched mantle type I (EMI)-like mantle (Fig. 7). In addition, the melt inclusions with high ${ }^{207} \mathrm{~Pb} /{ }^{206} \mathrm{~Pb}$ values in the andesites have higher $\mathrm{K}_{2} \mathrm{O}, \mathrm{P}_{2} \mathrm{O}_{5}, \mathrm{Rb}$ and $\mathrm{U}$ contents but lower $\mathrm{Pb}$ and $\mathrm{Cu}$ contents than the low- ${ }^{207} \mathrm{~Pb} /{ }^{206} \mathrm{~Pb}$ group melt inclusions, and none of the ${ }^{207} \mathrm{~Pb} /{ }^{206} \mathrm{~Pb}$ values in the melt inclusions from the basalt and andesites are correlated with their $\mathrm{MgO}$ contents (Fig. 8a).

\section{Discussion}

5.1. Genetic relationship between the melt inclusions and the basaltic volcanic rocks

The olivine-hosted melt inclusions from middle Okinawa Trough volcanic rocks show more variable element and $\mathrm{Pb}$ isotope compositions than the host whole-rock samples. The nature of the melt inclusions and their host olivines should be confirmed before discussing the origin and petrogenesis of the volcanic rocks. We believe that the melt inclusions and their host olivine phenocrysts are genetically related to the basaltic volcanic rocks for the following reasons: well-preserved melt inclusions are randomly distributed in the olivines from the volcanic rocks (Fig. 3c, d), suggesting that they are primary in origin (e.g., Roedder, 1979; Schiano, 2003). The fresh host olivines are generally euhedral to subhedral, have high $\mathrm{CaO}$ contents ( $>0.1 \mathrm{wt} \%)$ and contain Cr-spinel inclusions (Fig. 3c), implying that the olivines crystallized from a magmatic system rather than representing mantle-derived xenocrysts (e.g., Cameron, 1985; Kamenetsky et al., 2006; Gavrilenko et al., 2016). Moreover, the compositions of the melt inclusions in the basalt reflect the same compositional trends as those of the whole-rock samples (Fig. 5). Numerous studies have shown that the chemical compositions of olivine-hosted melt inclusions vary much more widely than the associated whole-rock compositions and that erupted wholerock compositions represent blended mixtures of a number of different melt compositions (e.g., Sobolev, 1996; Danyushevsky et al., 2000; Kamenetsky et al., 2012; Ren et al., 2017). Melt inclusions sample this variety and protect trapped melts from subsequent contamination or mixing. Therefore, melt inclusions can provide information on the initial magma composition and can be considered the unmixed equivalents of erupted lavas (e.g., Sobolev, 1996; Kamenetsky et al., 2012; Ren et al., 2017). These characteristics indicate that the studied melt inclusions and their host olivine phenocrysts are genetically related to the basaltic rocks (Ren et al., 2017) and can be used to constrain the origin and petrogenesis of the Okinawa Trough volcanic rocks.

The typical first-order trends of the major element oxides versus $\mathrm{MgO}$ (Fig. 5) show that the parental magma represented by the melt inclusions in the basalt reflects fractional crystallization magma evolution trends. More importantly, all melt inclusions in the basalt record nearly constant $\mathrm{Pb}$ isotope compositions (Figs. 7 and 8), supporting the inference that the parental magma in the basalt was derived from the same mantle source and underwent fractional crystallization during evolution of the magma (e.g., Park et al., 2010). Because the basaltic magma mainly underwent the evolution process of fractional crystallization, in this case, we can use the melt inclusions to reasonably estimate the magma source composition and discuss the contributions of enriched components to the mantle source. 

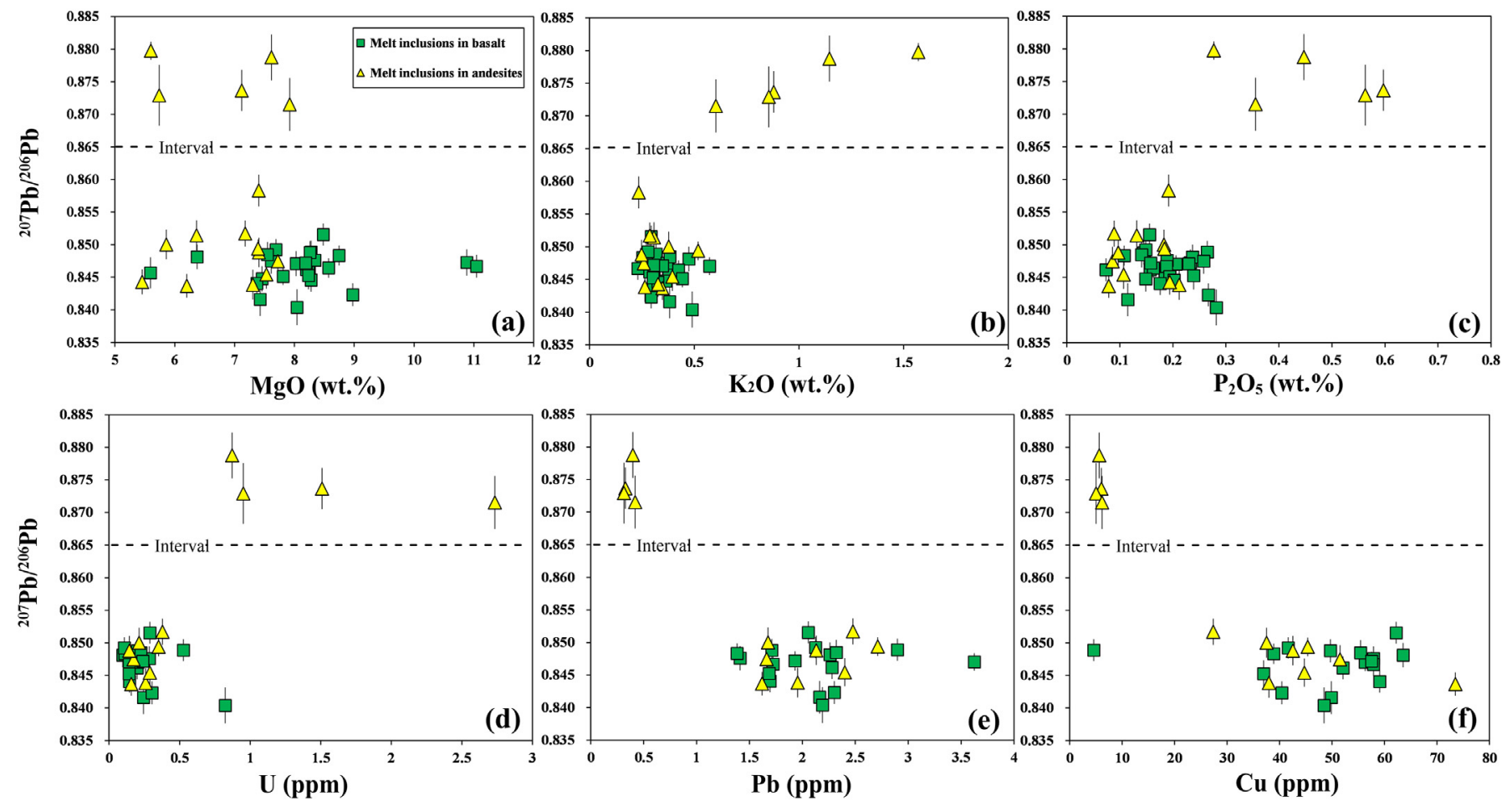

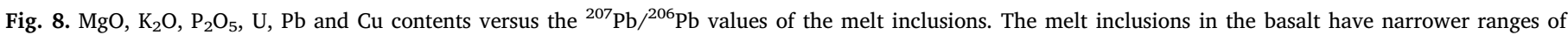
${ }^{207} \mathrm{~Pb} /{ }^{206} \mathrm{~Pb}$ values compared with those observed in the andesites.

\subsection{Implications for the contributions of the enriched components to the mantle source}

Indian Ocean-type mantle and Pacific Ocean-type mantle are the two major types of mantle in the western Pacific, with their dividing line comprising the Australian-Antarctic Discordance (Klein et al., 1988). Despite being located in the western Pacific, the small number of previously published basaltic whole-rock $\mathrm{Pb}$ isotope compositions in the middle Okinawa Trough all plot in the Indian Ocean-type mantle field and could imply the existence of Indian Ocean-type mantle rather than Pacific Ocean-type mantle (Hoang and Uto, 2006; Shu et al., 2017; Li et al., 2018). However, Hoang and Uto (2006) proposed that residual Pacific Ocean-type mantle exists below the Okinawa Trough based on the $\mathrm{Sr}-\mathrm{Nd}-\mathrm{Pb}$ isotope compositional features of basalts. Guo et al., 2016 also suggested that Indian Ocean-type mantle contributed to the formerly existing Pacific-type mantle. Therefore, understanding the origin of the Indian Ocean-type mantle is crucial for understanding the magma source under the Okinawa Trough. Indian Ocean-type mantle has been attributed to recycling of detached continental material in the shallow mantle (Escrig et al., 2004), recycling of oceanic crust plus sediment through plate subduction (Rehkämper and Hofmann, 1997) and contamination by deep-rooted mantle plumes (Storey et al., 1989; Wen, 2006). All of these models show that the Indian Ocean-type mantle represents a depleted mantle source that was contaminated by enriched components. Therefore, it is not important to determine whether the Indian Ocean-type mantle existed before the formation of the Okinawa Trough; instead, the key issue is determining how the depleted mantle was contaminated by enriched components.

Generally, the trace element compositions of magmas in subduction zones exhibit remarkable enrichment in $\mathrm{Pb}$ and LILEs relative to HFSEs and REEs (e.g., McCulloch and Gamble, 1991; Miller et al., 1994). Owing to their similar partition coefficients, most of these elements are rarely significantly modified during magmatic processes, such as crystallization and partial melting (e.g., Hawkesworth et al., 1993). Thus, the enrichment of LILEs and $\mathrm{Pb}$ in subduction zone magmas may reflect the addition of elements through plate subduction (e.g., McCulloch and
Gamble, 1991). Subducted sediment, hydrous fluids from altered oceanic basalt, and silicate melts derived from oceanic basalt and/or sediment comprise the major components of the subducted plate, and many investigations regard slab-derived fluids and melts as the most important agents for explaining the LILE and light REE enrichment and HFSE depletion in subduction zone magmas (e.g., Grove et al., 2002; Handley et al., 2007). The melt inclusions with low ${ }^{207} \mathrm{~Pb} /{ }^{206} \mathrm{~Pb}$ ratios in the basalt and andesites in this study are enriched in LILEs relative to HFSEs and REEs and exhibit negative $\mathrm{Nb}$ and $\mathrm{Ta}$ anomalies and positive $\mathrm{Pb}$ anomalies (Fig. 6). These characteristics can be reasonably interpreted as being due to the addition of materials from an enriched mantle source with a large amount of subducted plate components (McCulloch and Gamble, 1991). We introduce incompatible trace element ratios, which are mostly stable during partial melting or crystallization processes, to further evaluate the contributions of enriched components to the magma source. The concentration of Th in marine sediments and melts from altered oceanic crust (AOC) is usually more than two orders of magnitude greater than that in the mantle, and relative to REEs and HFSEs, Th is insoluble in fluids during subduction (Singer et al., 2007). Consequently, the presence of high $\mathrm{Th} / \mathrm{Yb}$ ratios in the magma after normalization with $\mathrm{Yb}$ indicates that partially melted sediments were added to the mantle source (e.g., Class et al., 2000) (Fig. 9a). At the same time, the $\mathrm{Nb} / \mathrm{Yb}$ ratios of the melt inclusions are higher than those of N-MORB (Fig. 9a), indicating that the enriched material is incorporated into the magma source. This is further supported by the high $\mathrm{Th} / \mathrm{Yb}$ and low $\mathrm{Ba} /$ La values in the melt inclusions, which are considered to be mainly derived from sediment or sediment melts (e.g., Sun et al., 2004) (Fig. 9b). In addition, the concentration of $\mathrm{Pb}$ in sediments and altered ocean crusts is typically one order of magnitude higher than that in the mantle. The $\mathrm{Pb} / \mathrm{Ce}$ ratio in sediment is relatively stable, is much higher than that of the mantle, and changes little during partial melting, fractional crystallization or other magmatic evolution processes (White and Duncan, 1996). In our samples, the $\mathrm{Pb} / \mathrm{Ce}$ ratios of the melt inclusions with low ${ }^{207} \mathrm{~Pb} /{ }^{206} \mathrm{~Pb}$ values in the basalt and andesites are much higher than those of typical MORB mantle, indicating that a certain percentage of $\mathrm{Pb}$-rich sediment 

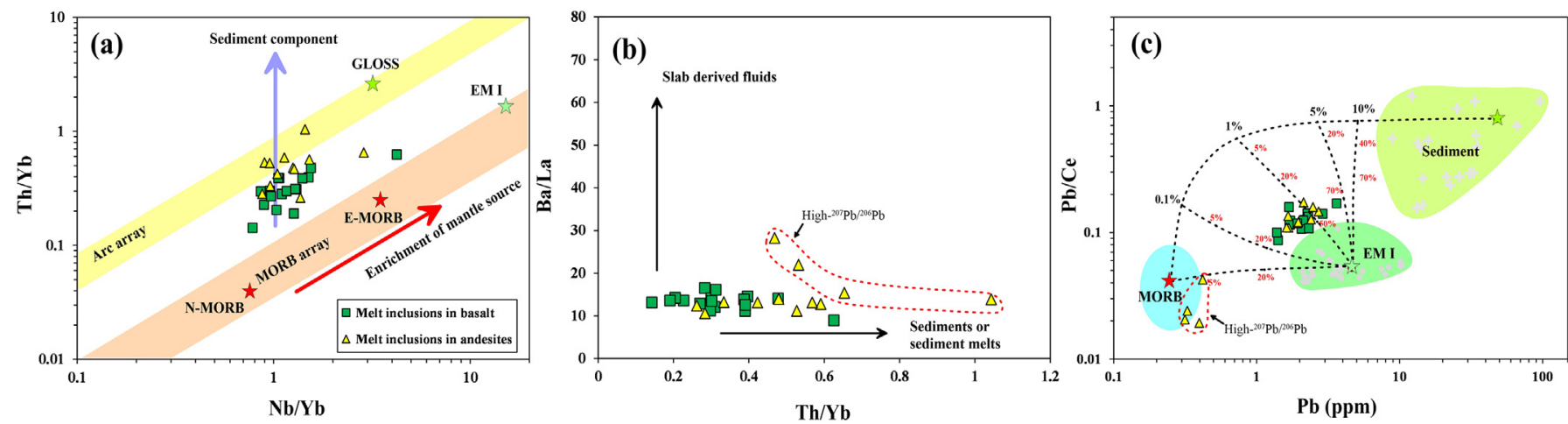

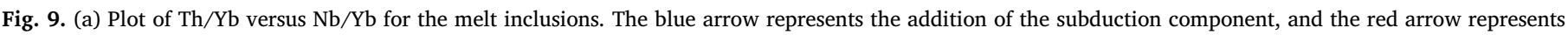

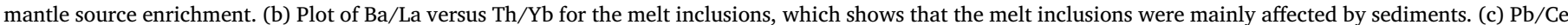

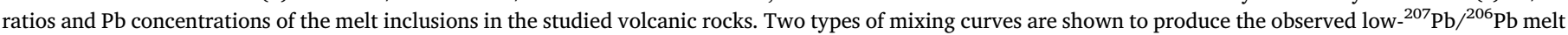

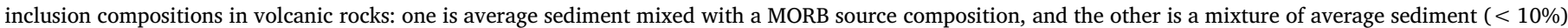

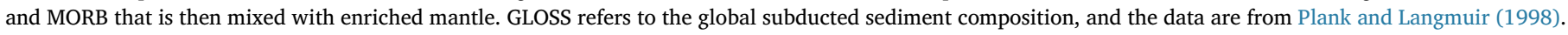

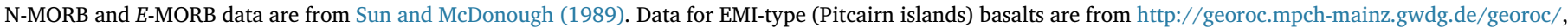

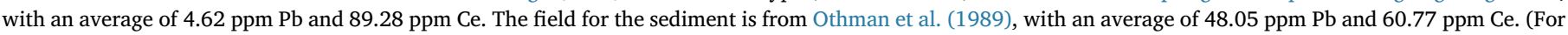
interpretation of the references to colour in this figure legend, the reader is referred to the web version of this article.)

components $(<10 \%)$ combined to form an enriched mantle in the magma sources of the middle Okinawa Trough (Fig. 9c).

\subsection{Origin of the enriched components}

The melt inclusions hosted by relatively high-Fo olivines could provide important information on the mantle source (e.g., Saal et al., 2005; Kent, 2008). As shown in Fig. 10, the Pb isotope compositions of the melt inclusions vary significantly compared with those observed in previously studied whole-rock samples, and the melt inclusions were divided into two groups. As the $\mathrm{Pb}$ isotope compositions of magmas remain constant during the processes of partial melting and

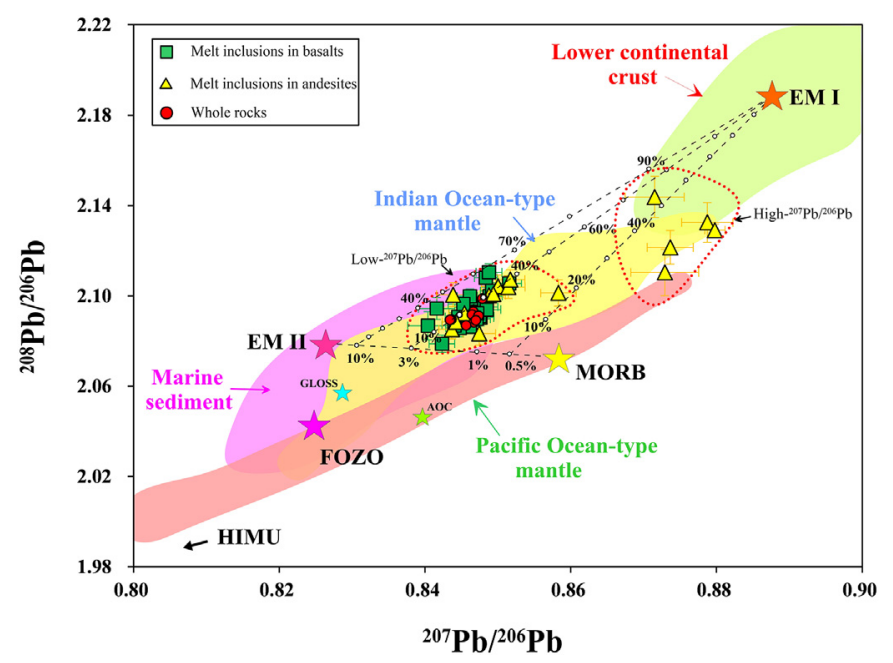

Fig. 10. Pb isotope characteristics of the melt inclusions and whole-rock samples compared with the modeling results. Mixing calculations show that mixing of MORB with $<10 \%$ of a subduction sediment component (EMII-like), followed by mixing with $10-40 \%$ recycled lower continental crust (EMI-like), could produce $\mathrm{Pb}$ isotope compositions similar to those of the melt inclusions with low ${ }^{207} \mathrm{~Pb} /{ }^{206} \mathrm{~Pb}$ ratios. The mixing lines assume that the ${ }^{207} \mathrm{~Pb} /{ }^{206} \mathrm{~Pb}$ and ${ }^{208} \mathrm{~Pb} /{ }^{206} \mathrm{~Pb}$ values of EMI, EMII and MORB are 0.888 and $2.19,0.826$ and 2.08 and 0.859 and 2.075, respectively (Saal et al., 1998, 2005). The $\mathrm{Pb}$ concentrations used for EMI, EMII and MORB are $0.5 \mathrm{ppm}$ (Weaver, 1991), 16.7 ppm (Straub et al., 2004) and 0.3 ppm (Sun and McDonough, 1989), respectively. The field for the lower continental crust is from Qian et al. (2017). The marine sediment data are from Hemming and McLennan (2001), Plank and Langmuir (1998) and Othman et al. (1989). fractionation, the melt inclusions of these two groups strongly support magma compositional heterogeneity. To explain the significant $\mathrm{Pb}$ isotope variability in the melt inclusions, an enriched mantle endmember with high ${ }^{207} \mathrm{~Pb} /{ }^{206} \mathrm{~Pb}-{ }^{208} \mathrm{~Pb} /{ }^{206} \mathrm{~Pb}$ values and relatively low ${ }^{207} \mathrm{~Pb} /{ }^{206} \mathrm{~Pb}-{ }^{208} \mathrm{~Pb} /{ }^{206} \mathrm{~Pb}$ values (Fig. 10) is required, which suggests that at least two different enriched components are responsible for the origin of the mantle source of the middle Okinawa Trough volcanic rocks.

All of the melt inclusions from the basalts and the majority of melt inclusions from the andesites have lower ${ }^{207} \mathrm{~Pb} /{ }^{206} \mathrm{~Pb}$ ratios and higher ${ }^{208} \mathrm{~Pb} /{ }^{206} \mathrm{~Pb}$ ratios than those of MORB on the $\mathrm{Pb}-\mathrm{Pb}$ isotopes plots (Fig. 10). High time-integrated ${ }^{238} \mathrm{U} /{ }^{204} \mathrm{~Pb}(=\mu$, HIMU) mantle, focus zone (FOZO)-like components and an EMII-like mantle are three potential sources that could produce low ${ }^{207} \mathrm{~Pb} /{ }^{206} \mathrm{~Pb}$ isotope compositions (e.g., Saal et al., 1998, 2005; Fig. 10). Because HIMU characteristics are commonly attributed to small-volume heterogeneities in the mantle, i.e., areas that are volumetrically smaller than the depleted mantle and exhibit abnormally low ${ }^{207} \mathrm{~Pb} /{ }^{206} \mathrm{~Pb}$ and ${ }^{208} \mathrm{~Pb} /{ }^{206} \mathrm{~Pb}$ isotope compositions, it seems to be a geodynamically less plausible endmember. FOZO components are common in the lower mantle, which may be a high ${ }^{3} \mathrm{He} /{ }^{4} \mathrm{He}$ mantle reservoir, and are always related to a mantle plume (Hart et al., 1992). However, the helium isotope compositions of the volcanic rocks from the Okinawa Trough range from 1.5 $\mathrm{R}_{\mathrm{A}}$ to $6.04 \mathrm{R}_{\mathrm{A}}$ (Yu et al., 2016), which are lower than the average worldwide MORB values ( $8 \pm 1 \mathrm{R}_{\mathrm{A}}$; Graham, 2002), suggesting that FOZO components are not a suitable candidate. Recent research has proposed that a subducted sediment component was involved in the Okinawa Trough magma source (e.g., Guo et al., 2016a, 2016b; Shu et al., 2017; Li et al., 2018a, 2018b, 2019), and this component is responsible for the high $\mathrm{Pb} / \mathrm{Ce}$ and $\mathrm{Th} / \mathrm{Yb}$ ratios in the melt inclusions in the basalt (Fig. 9), indicating that subducted sediment, as an enriched component with a low ${ }^{207} \mathrm{~Pb} /{ }^{206} \mathrm{~Pb}$ ratio (EMII-like end-member; Cousens et al., 1994), has played an important role in the genesis of the middle Okinawa Trough magma.

In addition, all of the $\mathrm{Pb}$ isotope compositions of the melt inclusions in the basalt and andesites extend toward an EMI-type isotopic endmember (Fig. 10), indicating that EMI-type isotopic components with high ${ }^{207} \mathrm{~Pb} /{ }^{206} \mathrm{~Pb}$ and ${ }^{208} \mathrm{~Pb} /{ }^{206} \mathrm{~Pb}$ ratios also contributed to the magma source composition. In general, mantle EMI components have low ${ }^{206} \mathrm{~Pb} /{ }^{204} \mathrm{~Pb}$ and ${ }^{143} \mathrm{Nd} /{ }^{144} \mathrm{Nd}$ and intermediate ${ }^{87} \mathrm{Sr} /{ }^{86} \mathrm{Sr}$ ratios (Zindler and Hart, 1986), and possible causes of these characteristics may be the recycling of oceanic crust and pelagic sediments (Weaver, 1991; Hauri, 1996; Hofmann, 1997, 2003; Lassiter and Hauri, 1998; Ren et al., 2017) 
or the recycling of the lower continental crust (Hanan et al., 2004; Willbold and Stracke, 2010). Some EMI-like characteristics of oceanic and continental basalts have often been attributed to the presence of recycled ancient oceanic crust and pelagic sediment in their mantle sources (Hofmann, 1997; Eisele et al., 2002; Murphy et al., 2002; Ren et al., 2017). However, as argued by Thirlwall (1997), the formation of an EMI-like signature with high ${ }^{207} \mathrm{~Pb} /{ }^{206} \mathrm{~Pb}$ ratios requires the source material to be isolated for a long period of time, i.e., $>1 \mathrm{Ga}$. Subducted Pacific oceanic crust in the Okinawa Trough can be precluded because of its relatively young age and low ${ }^{207} \mathrm{~Pb} /{ }^{206} \mathrm{~Pb}$ ratio (Saal et al., 1998, 2005; Kuritani et al., 2011; Fig. 10). The oxygen isotopes of basalts can be used to distinguish whether an EMI component represents oceanic sediment or recycled lower continental crust (e.g., Zhang et al., 2016). Generally, oceanic sediments tend to have higher $\delta^{18} \mathrm{O}$ values (up to 25\%; Kolodny and Epstein, 1976) than those of normal mantle due to low-temperature hydrothermal alteration occurring on the surface of the oceanic crust (e.g., Eiler et al., 1996; Zheng, 2012). The $\delta^{18}$ O values of basalts near the sampling location in this study were $6.0-6.3 \%$ (Honma et al., 1991), which are far from the sediment values but close to lower crustal granulite xenolith values $(\sim 7.0 \%$, Kempton and Harmon, 1992), meaning that recycled lower continental crust rather than oceanic sediments may be the major component of their EMI sources. This is consistent with the $\mathrm{Pb}$ isotope compositions, in which EMI end-members plot far from the field of marine sediments but within the field of the lower continental crust (Fig. 10). In addition, the trace element distributions of the melt inclusions in the basalt and the low ${ }^{207} \mathrm{~Pb} /{ }^{206} \mathrm{~Pb}$ group in andesites in this study are similar to those of the lower continental crust (Fig. 6), and the ratios of incompatible trace elements, such as $\mathrm{Ce} / \mathrm{Pb}=5.9-11.5$ and $\mathrm{Nb} / \mathrm{Yb}=0.8-4.2$, in melt inclusions are close to those of the lower continental crust $(\mathrm{Ce} / \mathrm{Pb}=5$, $\mathrm{Nb} / \mathrm{Yb}=3.3$; Rudnick and Gao, 2003). Therefore, components from the recycling of the lower continental crust with relatively high ${ }^{207} \mathrm{~Pb} /{ }^{206} \mathrm{~Pb}$ and high ${ }^{208} \mathrm{~Pb} /{ }^{206} \mathrm{~Pb}$ ratios may have been involved in the source of this EMI-type end-member.

To explain the $\mathrm{Pb}$ isotope variability of the majority of melt inclusions in the low- ${ }^{207} \mathrm{~Pb} /{ }^{206} \mathrm{~Pb}$ group, we modeled a mixture of Pacific Ocean-type mantle (MORB) and EMI-like and EMII-like materials, wherein the EMI-like component was derived from the lower continental crust and the EMII-like component was derived from the subducted sediments associated with the Philippine Sea Plate (Fig. 10). The modeled results indicate that the input of $<10 \%$ EMII-like subduction sediments to a Pacific Ocean-type mantle source, followed by mixing with different proportions of EMI-like lower continental crust (10-40\%), can explain the isotopic variations observed in the low- ${ }^{207} \mathrm{~Pb} /{ }^{206} \mathrm{~Pb}$ group melt inclusions in the basalt and andesites (Fig. 10).

The small amount of melt inclusions with high ${ }^{207} \mathrm{~Pb} /{ }^{206} \mathrm{~Pb}$ ratios, high $\mathrm{K}_{2} \mathrm{O}, \mathrm{P}_{2} \mathrm{O}_{5}, \mathrm{Rb}$ and $\mathrm{U}$ contents and low $\mathrm{Pb}$ and $\mathrm{Cu}$ contents in andesites represent an important finding of this study, as they are far from the range determined from the melt inclusions in basalt (Figs. 8 and 10). In subduction zones, continental crust, AOC, and subducted sediments may be potential sources for such enriched component melts with high ${ }^{207} \mathrm{~Pb} /{ }^{206} \mathrm{~Pb}$ ratios. The high ${ }^{207} \mathrm{~Pb} /{ }^{206} \mathrm{~Pb}$ compositions of the melt inclusions in the andesites also have high $\mathrm{K}_{2} \mathrm{O}$ contents (Fig. $8 \mathrm{~b}$ ), and high $\mathrm{K}_{2} \mathrm{O}$ volcanic rocks have been found in the Ryukyu Arc (Shinjo et al., 1999), the Northern Taiwan Volcanic Zone (Wang et al., 2004) and the Okinawa Trough (Zhang et al., 2018), which suggests that a potassium-rich source may have been present in this area. Studies have shown that such potassium-rich melts may represent a small degree of partial melting of the phlogopite-bearing garnet-peridotites from the sub-continental lithospheric mantle (SCLM), which has been metasomatized by delaminated, old lower continental crust (Wang et al., 2004; Tolstykh et al., 2012; Chu et al., 2013). However, these high- ${ }^{207} \mathrm{~Pb} /{ }^{206} \mathrm{~Pb}$ group melt inclusions have low $\mathrm{Pb}$ and $\mathrm{Cu}$ contents and high $\mathrm{P}_{2} \mathrm{O}_{5}, \mathrm{Rb}$ and $\mathrm{U}$ contents (Fig. 8), which are clearly different characteristics than those of the lower continental crust (Fig. 6)
(Rudnick and Gao, 2003). The elements $\mathrm{U}, \mathrm{Pb}, \mathrm{Ce}$ and $\mathrm{Nb}$ can undergo high degrees of fractionation during subduction processes. $\mathrm{U}$ and $\mathrm{Pb}$ are more mobile and $\mathrm{Nb}$ less mobile than Ce during the dehydration of slabs (e.g., McCulloch and Gamble, 1991). Therefore, the high $\mathrm{Pb} / \mathrm{Ce}$ and low $\mathrm{Nb} / \mathrm{U}$ ratios may indicate the addition of slab-derived fluids, which is inconsistent with the low $\mathrm{Pb} / \mathrm{Ce}$ ratios of these melt inclusions. In addition, the high ${ }^{207} \mathrm{~Pb} /{ }^{206} \mathrm{~Pb}$ compositions of the melt inclusions are far from the range of sediment and AOC in Fig. 10, suggesting that the AOC and subduction sediments cannot be the main source of these high- ${ }^{207} \mathrm{~Pb} /{ }^{206} \mathrm{~Pb}$ melts. During magma evolution, the fractionation of $\mathrm{Pb}$ and $\mathrm{Cu}$-rich sulfide phases during magmatic differentiation could shift $\mathrm{Pb}$ and $\mathrm{Cu}$ to lower contents in residual melts, such as in the case of the negative $\mathrm{Pb}$ anomaly clinopyroxene in andesites and rhyolites from the middle Okinawa Trough (Li et al., 2020b), and may be a potential cause of the low $\mathrm{Pb}$ and $\mathrm{Cu}$ contents in the high- ${ }^{207} \mathrm{~Pb} /{ }^{206} \mathrm{~Pb}$ group melt inclusions. In addition, melts from carbonated oceanic crust can also show high $\mathrm{P}_{2} \mathrm{O}_{5}$ contents and low $\mathrm{Pb} / \mathrm{Ce}$ ratios (e.g., Zhang et al., 2017). However, due to insufficient data and the lack of further constraints from other isotopic compositions, further work needs to be carried out to identify the exact source of the high- ${ }^{207} \mathrm{~Pb} /{ }^{206} \mathrm{~Pb}$ group melt inclusions.

\subsection{Petrogenesis of the volcanic rocks inferred from the melt inclusions}

The basalts may have been formed by the fractional crystallization of an isotopically homogeneous mantle magma source, as evidenced by studies of melt inclusions, which is consistent with the results of studies on whole-rock samples (e.g., Shinjo, 1999; Shinjo and Kato, 2000; Li et al., 2018). However, the genesis of the andesitic volcanic rocks in the Okinawa Trough is poorly understood. The AFC process of basaltic magma (Shinjo and Kato, 2000) and magma mixing between basaltic and rhyolitic melts (Ishizuka et al., 1990) are two main models that have been proposed to explain the origins of andesites in the Okinawa Trough. However, these results were based on geochemical analyses of whole-rock samples that erupted as magmatic end-products, which represent only an 'average' composition formed by a variety of complex processes and do not provide robust evidence for magma mixing in their evolutionary process (Sobolev, 1996; Kamenetsky et al., 2012; Ren et al., 2005, 2017). The compositions of the melt inclusions in the andesites represent a more primitive magma, which had a larger range of variation in its major and trace element contents than the whole-rock samples and had no compositional correlations with the $\mathrm{MgO}$ content (Figs. 5 and 6), thus indicating that simple fractional crystallization cannot explain the content change during magma evolution. More importantly, the $\mathrm{Pb}$ isotopes of these melt inclusions span a wide range, with most falling into the basalt field (low- ${ }^{207} \mathrm{~Pb} /{ }^{206} \mathrm{~Pb}$ group); however, some showed high ${ }^{207} \mathrm{~Pb} /{ }^{206} \mathrm{~Pb}$ ratios that were not correlated with the associated $\mathrm{MgO}$ contents (Fig. 8a), which reflects the involvement of components with high ${ }^{208} \mathrm{~Pb} /{ }^{206} \mathrm{~Pb}$ and ${ }^{207} \mathrm{~Pb} /{ }^{206} \mathrm{~Pb}$ ratios. This finding indicates that crystallization-driven differentiation and partial melting may be the main (but not the only) process producing andesitic volcanic rocks, whereas the mixing of magmas with different elemental and isotopic compositions is needed to explain the melt inclusion compositions in the andesites observed in this study.

To summarize the above discussion, we present a petrogenetic process that explains the origin and evolution of melt inclusions with a wide range of $\mathrm{Pb}$ isotope compositions. Due to Philippine Sea Plate subduction, EMII-like melts were released from sediments by dehydration of the subducting slab and interacted with the overlying mantle. The injection of EMII-like subducted sediment melts or fluid and EMIlike recycled lower continental crust components into the mantle source produced the low ${ }^{207} \mathrm{~Pb} /{ }^{206} \mathrm{~Pb}$ group components recorded in the basalts and melt inclusions (Fig. 10). Due to the high proportion occupied by the $10 \mathrm{w}^{207} \mathrm{~Pb} /{ }^{206} \mathrm{~Pb}$ group in the melt inclusions in andesites, crystallization-driven differentiation and partial melting of basaltic magma may represent the main process that produced the andesitic 
magma in the Okinawa Trough, which inherited the low ${ }^{207} \mathrm{~Pb} /{ }^{206} \mathrm{~Pb}$ compositions of the basaltic magma. At the same time, a small amount of hybrid melt mixed with the andesitic magma, as reflected by the high ${ }^{207} \mathrm{~Pb} /{ }^{206} \mathrm{~Pb}$ ratios, high $\mathrm{P}_{2} \mathrm{O}_{5}, \mathrm{Rb}$ and $\mathrm{U}$ contents and low $\mathrm{Pb}$ and $\mathrm{Cu}$ contents in the melt inclusions. The mixing extensively affected the magma compositions and resulted in magma heterogeneity beneath the Okinawa Trough. Both low- and high- ${ }^{207} \mathrm{~Pb} /{ }^{206} \mathrm{~Pb}$ melt compositions have been found in melt inclusions from individual volcanic rocks, whereas previous studies of whole-rock samples only presented low ${ }^{207} \mathrm{~Pb} /{ }^{206} \mathrm{~Pb}$ values, suggesting that evidence of exotic melts is readily obscured in the whole-rock compositions formed by mixing processes and that magma source characteristics should be better understood before whole-rock data are used to constrain the history of magma evolution in the Okinawa Trough.

\section{Conclusions}

We present the major and trace element compositions and $\mathrm{Pb}$ isotope compositions of olivine-hosted melt inclusions from basalt and andesites in the middle Okinawa Trough. The geochemical characteristics of the melt inclusions indicate the presence of enriched components in the magma source. Both high- and low- ${ }^{207} \mathrm{~Pb} /{ }^{206} \mathrm{~Pb}$ compositions were found in melt inclusions in individual volcanic rocks, suggesting that a compositionally heterogeneous magma was produced by mixing of the magma source with different proportions of recycled lower continental crust and subducted sediments. The variable major element compositions and homogeneous low- ${ }^{207} \mathrm{~Pb} /{ }^{206} \mathrm{~Pb}$ compositions of the melt inclusions in basalt suggest that the basalt was derived from a mantle source that had undergone fractional crystallization during the evolutions of magma, while the production of andesitic magma occurred through mixing between low- ${ }^{207} \mathrm{~Pb} /{ }^{206} \mathrm{~Pb}$ components, which were similar to the basalt, and a high- ${ }^{207} \mathrm{~Pb} /{ }^{206} \mathrm{~Pb}$ component, which had low $\mathrm{Pb}$ and $\mathrm{Cu}$ contents but high $\mathrm{K}_{2} \mathrm{O}, \mathrm{P}_{2} \mathrm{O}_{5}, \mathrm{Rb}$ and $\mathrm{U}$ contents. This study of melt inclusions provides some key information on the composition of the magma source and the genesis of volcanic rocks that may be obscured in whole-rock analyses.

Supplementary data to this article can be found online at https:// doi.org/10.1016/j.chemgeo.2020.119600.

\section{Declaration of competing interest}

No conflict of interest exits in the submission of this manuscript and due care has been taken to ensure the integrity of the work.

\section{Acknowledgements}

We extend our heartfelt thanks to the Institute of Oceanology, Chinese Academy of Sciences for supplying the samples and to Dr. Zhiqing Lai of the Key Laboratory of Submarine Geosciences and Prospecting Techniques, Ministry of Education, Ocean University of China for assisting with our electron probe microanalysis of melt inclusions and their host olivines. Constructive reviews by two anonymous reviewers and the editorial work of Catherine Chauvel are greatly appreciated. This work was supported by the National Natural Science Foundation of China (Grant No. 91958213), the National Programme on Global Change and Air-Sea Interaction (Grant No. GASIGEOGE-02), the Open Fund of the Key Laboratory of Marine Geology and Environment, Chinese Academy of Sciences (Grant No. MGE2019KG07), the International Partnership Program of Chinese Academy of Sciences (Grant No. 133137KYSB20170003), the National Special Fund for the 13th Five Year Plan of COMRA (Grant No. DY135G2-1-02), the Special Fund for the Taishan Scholar Program of Shandong Province (Grant No. ts201511061), the Qingdao Postdoctoral Applied Research Project, the National Key Basic Research Program of China (Grant No. 2013CB429700) and Shandong Provincial Natural
Science Foundation, China (Grant No. ZR2019BD010).

\section{References}

Arai, R., Kodaira, S., Yuka, K., Takahashi, T., Miura, S., Kaneda, Y., 2017. Crustal structure of the southern Okinawa Trough: symmetrical rifting, submarine volcano, and potential mantle accretion in the continental back-arc basin. J. Geophys. Res. Solid Earth 122, 622-641. https://doi.org/10.1002/2016JB013448.

Cameron, W.E., 1985. Petrology and origin of primitive lavas from the Troodos ophiolite Cyprus. Contrib. Mineral. Petrol. 89 (2), 239-255. https://doi.org/10.1007/ BF00379457.

Carpentier, M., Chauvel, C., Mattielli, N., 2008. Pb-Nd isotopic constraints on sedimentary input into the Lesser Antilles arc system. Earth Planet. Sci. Lett. 272, 199-211. https://doi.org/10.1016/j.epsl.2008.04.036.

Chauvel, C., Blichert-Toft, J., 2001. A hafnium isotope and trace element perspective on melting of the depleted mantle. Earth Planet. Sci. Lett. 190, 137-151. https://doi. org/10.1016/S0012-821X(01)00379-X.

Chen, Z., Zeng, Z., Yin, X., Wang, X., Zhang, Y., Chen, S., 2018. Petrogenesis of highly fractionated rhyolites in the southwestern Okinawa Trough: constraints from wholerock geochemistry data and Sr-Nd-Pb-O isotopes. Geol. J. 54, 316-332. https://doi. org/10.1002/gi.3179.

Chu, Z.Y., Harvey, J., Liu, C.Z., Guo, J.H., Wu, F.Y., Tian, W., Zhang, Y.L., Yang, Y.H., 2013. Source of highly potassic basalts in Northeast China: evidence from Re-Os, Sr-Nd-Hf isotopes and PGE geochemistry. Chem. Geol. 357, 52-66. https://doi.org/ 10.1016/j.chemgeo.2013.08.007.

Church, S.E., Tatsumoto, M., 1975. Lead isotope relations in oceanic ridge basalts from the Juan de Fuca-Gorda Ridge area, N.E. Pacific Ocean. Contrib. Mineral. Petrol. 53, 253-279. https://doi.org/10.1007/BF00382443.

Class, C., Miller, D.M., Langmuir, C.H., 2000. Distinguishing melt and fluid subduction components in Umnak Volcanics, Aleutian arc. Geochem. Geophys. Geosyst. 1, 927-928. https://doi.org/10.1029/1999GC000010.

Cohen, R.S., O'Nions, R.K., 1982. The lead, neodymium and strontium isotopic structure of ocean ridge basalts. J. Petrol. 23, 299-324. https://doi.org/10.1093/petrology/23. 3.299 .

Cohen, R.S., Evensen, N.M., Hamilton, P.J., O’Nions, R.K., 1980. U-Pb, Sm-Nd and Rb-Sr systematics of mid-ocean ridge basalt glasses. Nature 23, 149-152. https://doi.org/ 10.1038/283149a0.

Cousens, B.L., Allan, J.F., Gorton, M.P., 1994. Subduction-modified pelagic sediments as the enriched component in back-arc basalts from the Japan Sea: ocean drilling program sites 797 and 794. Contrib. Mineral. Petrol. 117 (4), 421-434. https://doi.org/ 10.1007/BF00307275.

Danyushevsky, L.V., Plechov, P., 2011. Petrolog 3: integrated software for modeling crystallization processes. Geochem. Geophys. Geosyst. 12. https://doi.org/10.1029/ 2011GC003516.

Danyushevsky, L.V., Della-Pasqua, F.N., Sokolov, S., 2000. Re-equilibration of melt inclusions trapped by magnesian olivine phenocrysts from subduction-related magmas: petrological implications. Contrib. Mineral. Petrol. 138, 68-83. https://doi.org/10. 1007/PL00007664.

Danyushevsky, L.V., McNeill, A.W., Sobolev, A.V., 2002. Experimental and petrological studies of melt inclusions in phenocrysts from mantle-derived magmas: an overview of techniques, advantages and complications. Chem. Geol. 183, 5-24. https://doi. org/10.1016/S0009-2541(01)00369-2.

Dosso, L., Bougault, H., Beuzart, P., Calvez, J.Y., Joron, J.L., 1988. The geochemical structure of the Southeast Indian Ridge. Earth Planet. Sci. Lett. 88, 47-59. https:// doi.org/10.1016/0012-821X(88)90045-3.

Dupre, B., Allegre, C.J., 1983. Pb-Sr isotope variation in Indian Ocean Basalts and mixing phenomena. Nature 303, 142-146. https://doi.org/10.1038/303142a0.

Eiler, J.M., Farley, K.A., Valley, J.W., Hofmann, A.W., Stolper, E.M., 1996. Oxygen isotope constraints on the sources of Hawaiian volcanism. Earth Planet. Sci. Lett. 144 (3/4), 453-468. https://doi.org/10.1016/S0012-821X(96)00170-7.

Eisele, J., Sharma, M., Galer, S.J.G., Blichert-Toft, J., Devey, C.W., Hofmann, A.W., 2002. The role of sediment recycling in EM-1 inferred from $\mathrm{Os}, \mathrm{Pb}, \mathrm{Hf}, \mathrm{Nd}, \mathrm{Sr}$ isotope and trace element systematics of the Pitcairn hotspot. Earth Planet. Sci. Lett. 196, 197-212. https://doi.org/10.1016/S0012-821X(01)00601-X.

Elburg, M., Vroon, P., Wagt, B.V.D., Tchalikian, A., 2005. Sr and Pb isotopic composition of five usgs glasses (BHVO-2G, BIR-1G, BCR-2G, TB-1G, NKT-1G). Chem. Geol. 223 (4), 196-207. https://doi.org/10.1016/j.chemgeo.2005.07.001.

Escrig, S., Capmas, F., Dupré, B., Allegre, C.J., 2004. Osmium isotopic constraints on the nature of the DUPAL anomaly from Indian mid-ocean-ridge basalts. Nature 431 (7004), 59-63. https://doi.org/10.1038/nature02904.

Ford, C.E., Russel, D.G., Craven, J.A., Fisk, M.R., 1983. Olivine-liquid equilibria: temperature, pressure and composition dependence of the crystal/liquid cation partition coefficients for Mg, Fe2+, Ca and Mn. J. Petrol. 24, 256-265. https://doi.org/10. 1093/petrology/24.3.256

Gasparon, M., Varne, R., 1998. Crustal assimilation versus subducted sediment input in west Sunda arc volcanics: an evaluation. Mineral. Petrol. 64, 89-117. https://doi. org /10.1007/BF01226565.

Gavrilenko, M., Herzberg, C., Vidito, C., Carr, M.J., Tenner, T., Ozerov, A., 2016. A calcium-in-olivine geohygrometer and its application to subduction zone magmatism. J. Petrol. 57 (9), 1811-1832. https://doi.org/10.1093/petrology/egw062.

Graham, D.W., 2002. Noble gas isotope geochemistry of mid-ocean ridge and ocean island basalts: characterization of mantle source reservoirs. Rev. Mineral. Geochem. 47 (1), 247-317. https://doi.org/10.2138/rmg.2002.47.8.

Grove, T.L., Parman, S.W., Bowring, S.A., Price, R.C., Baker, M.B., 2002. The role of an $\mathrm{H}_{2} \mathrm{O}$ rich fluid component in the generation of primitive basaltic andesites and 
andesites from the Mt. Shasta region, N California. Contrib. Mineral. Petrol. 142, 375-396. https://doi.org/10.1007/s004100100299.

Guo, K., Zhai, S., Yu, Z., Cai, Z., Zhang, X., 2016a. Sr-Nd-Pb isotopic geochemistry of phenocrysts in pumice from the Central Okinawa trough. Geol. J. 51 (S1), 368-375. https://doi.org/10.1002/gj.2823.

Guo, K., Zhai, S., Yu, Z., Wang, S., Zhang, X., Wang, X., 2016b. Geochemical and Sr-Nd$\mathrm{Pb}-\mathrm{Li}$ isotopic characteristics of volcanic rocks from the Okinawa Trough: implications for the influence of subduction components and the contamination of crustal materials. J. Marine Syst. 180, 140-151. https://doi.org/10.1016/j.jmarsys.2016.11. 009.

Hamelin, B., Dupre, B.C., Allegre, J., 1984. Lead-strontium isotopic variations along the East Pacific Rise and the Mid Atlantic Ridge: a comparative study. Earth Planet. Sci. Lett. 67, 340-350. https://doi.org/10.1016/0012-821X(84)90173-0.

Hanan, B.B., Schilling, J.G., 1989. Easter microplate evolution, Pb isotope evidence. J. Geophys. Res. 94, 7432-7448. https://doi.org/10.1029/JB094iB06p07432.

Hanan, B.B., Blichert-Toft, J., Pyle, D.G., Christie, D.M., 2004. Contrasting origins of the upper mantle revealed by hafnium and lead isotopes from the Southeast Indian Ridge. Nature 432, 91-94. https://doi.org/10.1038/nature03181.

Handley, H., Macpherson, C., Davidson, J., Berlo, K., Lowry, D., 2007. Constraining fluid and sediment contributions to subduction-related magmatism in Indonesia, Ijen Volcanic Complex. J. Petrol. 48, 1155-1183. https://doi.org/10.1093/petrology/ egm013.

Hart, S.R., Hauri, E.H., Oschmann, L.A., 1992. Mantle plumes and entrainment: isotope evidence. Science 256, 517-520. https://doi.org/10.1126/science.256.5056.517.

Hartley, M.E., Thordarson, T., Fitton, J.G., 2013. Oxygen isotopes in melt inclusions and glasses from the Askja volcanic system, North Iceland. Geochim. Cosmochim. Acta 123, 55-73. https://doi.org/10.1016/j.gca.2013.09.008.

Hauri, E.H., 1996. Major-element variability in the Hawaiian mantle plume. Nature 382, 415-419. https://doi.org/10.1038/382415a0.

Hawkesworth, C.J., Hergt, J.M., Ellam, R.M., McDermott, F., 1991. Element fluxes associated with subduction related magmatism. Philos. Trans. R. Soc. Lond. 335, 393-405. https://doi.org/10.1098/rsta.1991.0054.

Hawkesworth, C.J., Gallagher, K., Hergt, J.M., McDermott, F., 1993. Mantle and slab contributions in arc magmas. Annu. Rev. Earth Planet. Sci. 21, 175-204. https://doi. org/10.1146/annurev.ea.21.050193.001135.

Hemming, S.R., McLennan, S.M., 2001. Pb isotope compositions of modern deep sea turbidites. Earth Planet. Sci. Lett. 184 (2), 489-503. https://doi.org/10.1016/S0012$821 \mathrm{X}(00) 00340-\mathrm{X}$.

Hoang, N., Uto, K., 2006. Upper mantle isotopic components beneath the Ryukyu arc system: evidence for 'back-arc' entrapment of Pacific MORB mantle. Earth Planet. Sci. Lett. 249 (3-4), 229-240. https://doi.org/10.1016/j.epsl.2006.07.021.

Hofmann, A.W., 1997. Mantle geochemistry: the message from oceanic volcanism. Nature 385, 219-229. https://doi.org/10.1038/385219a0.

Hofmann, A.W., 2003. Sampling mantle heterogeneity through oceanic basalts: Isotopes and trace elements. In: Holland, H.D., Turekian, K.K. (Eds.), Treatise on Geochemistry. Pergamon, Oxford, pp. 61-101. https://doi.org/10.1016/B0-08 043751-6/02123-X.

Honma, H., Kusakabe, M., Kagami, H., Iizumi, S., Sakai, H., Kodama, Y., Kimura, M., 1991. Major and trace element chemistry and $\mathrm{D} / \mathrm{H},{ }^{18} \mathrm{O} /{ }^{16} \mathrm{O},{ }^{87} \mathrm{Sr} /{ }^{86} \mathrm{Sr}$ and ${ }^{143} \mathrm{Nd} /{ }^{144} \mathrm{Nd}$ ratios of rocks from the spreading center of the Okinawa Trough, a marginal back-arc basin. Geochem. J. 25 (2), 121-136. https://doi.org/10.2343/ geochemj.25.121.

Ishizuka, H., Kawanobe, Y., Sakai, H., 1990. Petrology and geochemistry of volcanic rocks dredged from the Okinawa Trough, an active back-arc basin. Geochem. J. 24 (2), 75-92. https://doi.org/10.2343/geochemj.24.75.

Ito, E., White, W.M., Gopel, C., 1987. The O, Sr, Nd and Pb isotope geochemistry of MORB. Chem. Geol. 2, 157-176. https://doi.org/10.1016/0009-2541(87)90083-0.

Kamenetsky, V.S., Elburg, M., Arculus, R., Thomas, R., 2006. Magmatic origin of low-Ca olivine in subduction-related magmas: Co-existence of contrasting magmas. Chem. Geol. 233, 346-357. https://doi.org/10.1016/j.chemgeo.2006.03.010.

Kamenetsky, V.S., Chung, S.L., Kamenetsky, M.B., Kuzmin, D.V., 2012. Picrites from the Emeishan large igneous province, SW China: a compositional continuum in primitive magmas and their Respective Mantle sources. J. Petrol. 53, 2095-2113. https://doi. org/10.1093/petrology/egs045.

Kempton, P.D., Harmon, R.S., 1992. Oxygen isotope evidence for large-scale hybridization of the lower crust during magmatic underplating. Geochim. Cosmochim. Acta 56 (3), 971-986. https://doi.org/10.1016/0016-7037(92)90041-G.

Kent, A.J.R., 2008. Melt inclusions in basaltic and related volcanic rocks. Rev. Mineral. Geochem. 69, 273-331. https://doi.org/10.2138/rmg.2008.69.8.

Klein, E.M., Langmuir, C.H., Zindler, A., Staudigel, H., Hamelin, B., 1988. Isotope evidence of a mantle convection boundary at the australian-antarctic discordance. Nature 333 (6174), 623-629. https://doi.org/10.1038/333623a0.

Kolodny, Y., Epstein, S., 1976. Stable isotope geochemistry of deep sea cherts. Geochim. Cosmochim. Acta 40 (10), 1195-1209. https://doi.org/10.1016/0016-7037(76) 90155-1.

Kuritani, T., Ohtani, E., Kimura, J.I., 2011. Intensive hydration of the mantle transition zone beneath China caused by ancient slab stagnation. Nat. Geosci. 4 (10), 713-716. https://doi.org/10.1038/ngeo1250.

Lassiter, J.C., Hauri, E.H., 1998. Osmium-isotope variations in Hawaiian lavas: evidence for recycled oceanic lithosphere in the Hawaiian plume. Earth Planet. Sci. Lett. 164, 483-496. https://doi.org/10.1016/S0012-821X(98)00240-4.

Li, X.H., Zeng, Z.G., Chen, S., Ma, Y., Yang, H.X., Zhang, Y.X., Chen, Z.X., 2018a. Geochemical and $\mathrm{Sr}-\mathrm{Nd}-\mathrm{Pb}$ isotopic of volcanic rocks from Iheya Ridge, the middle Okinawa Trough: implications for the petrogenesis and mantle source. Acta Oceanol. Sin. 37 (1), 73-88. https://doi.org/10.1007/s13131-017-1118-8.

Li, X.H., Zeng, Z.G., Wang, X.Y., Chen, S., Ma, Y., Yang, H.X., Zhang, Y.X., Chen, Z.X., 2018b. Petrogenesis of basalt from the middle Okinawa Trough: New insights from olivine-hosted melt inclusions. Geol. J. 53 (6), 3129-3146. https://doi.org/10.1002/ gj. 3150 .

Li, X.H., Zeng, Z.G., Yang, H.X., Yin, X.B., Wang, X.Y., Chen, S., Ma, Y., Guo, K., 2019. Geochemistry of silicate melt inclusions in middle and southern Okinawa Trough Rocks: implications for petrogenesis and variable subducted sediment component injection. Geol. J. 54, 1160-1189. https://doi.org/10.1002/gj.3217.

Li, X.H., Zeng, Z.G., Dan, W., Yang, H.X., Wang, X.Y., Fang, B.W., Li, Q.L., 2020a. Source lithology and crustal assimilation recorded in low $\delta^{18} \mathrm{O}$ olivine from Okinawa Trough, back-arc basin. Lithos. https://doi.org/10.1016/j.lithos.2020.105444.

Li, X.H., Zeng, Z.G., Yang, H.X., Zhao, Y.T., Yin, X.B., Wang, X.Y., Chen, S., Qi, H.Y., Guo, K., 2020b. Integrated major and trace element study of clinopyroxene in basic, intermediate and acidic volcanic rocks from the middle Okinawa Trough: insights into petrogenesis and the influence of subduction component. Lithos. https://doi.org/10. 1016/j.lithos.2019.105320.

Liu, B., Li, S., Suo, Y., Li, G., Dai, L., Somerville, I.D., Guo, L., Zhao, S., Yu, S., 2016. The geological nature and geodynamics of the Okinawa Trough, Western Pacific. Geol. J. 51 (S1), 416-428. https://doi.org/10.1002/gj.2774.

Maclennan, J., 2008. Lead isotope variability in olivine-hosted melt inclusions from Iceland. Geochim. Cosmochim. Acta 72 (16), 4159-4176. https://doi.org/10.1016/j. gca.2008.05.034.

Mahoney, J.J., Natland, J.H., White, W.M., Poreda, R., Bloomer, S.H., Fisher, R.L., Baxter, A.N., 1989. Isotopic and geochemical provinces of the western Indian Ocean spreading centers. J. Geophys. Res. 94, 4033-4052. https://doi.org/10.1029/ JB094iB04p04033.

Mahoney, J.J., Sinton, J.M., Kurz, M.D., Macdougall, J.D., Spencer, K.J., Lugmair, G.W., 1994. Isotope and trace element characteristics of a super-fast spreading ridge: East Pacific rise, $13^{\circ}-23^{\circ}$ S. Earth Planet. Sci. Lett. 121, 173-193. https://doi.org/10. 1016/0012-821X(94)90039-6.

McCulloch, M.T., Gamble, J.A., 1991. Geochemical and geodynamical constraints on subduction zone magmatism. Earth Planet. Sci. Lett. 102, 358-374. https://doi.org/ 10.1016/0012-821X(91)90029-H.

Miller, D.M., Goldstein, S.L., Langmuir, C.H., 1994. Cerium/lead and lead isotope ratios in arc magmas and the enrichment of lead in the continents. Nature 368, 514-519. https://doi.org/10.1038/368514a0.

Murphy, D.T., Collerson, K.D., Kamber, B.S., 2002. Lamproites from Gaussberg, Antarctica: possible transition zone melts of Archaean subducted sediments. J. Petrol. 43, 981-1001. https://doi.org/10.1093/petrology/43.6.981.

Othman, D.B., White, W.M., Patchett, J., 1989. The geochemistry of marine sediments, island arc magma genesis, and crust-mantle recycling. Earth Planet. Sci. Lett. 94 (1-2), 1-21. https://doi.org/10.1016/0012-821X(89)90079-4.

Park, S.H., Lee, S.M., Kamenov, G.D., Kwon, S.T., Lee, K.Y., 2010. Tracing the origin of subduction components beneath the South East rift in the Manus Basin, Papua New Guinea. Chem. Geol. 269 (3-4), 339-349. https://doi.org/10.1016/j.chemgeo.2009. 10.008 .

Pearce, J.A., Peate, D.W., 1995. Tectonic implications of the composition of volcanic arc magmas. Annu. Rev. Earth Planet. Sci. 24, 251-285. https://doi.org/10.1146/ annurev.ea.23.050195.001343.

Pilet, S., Baker, M.B., Muntener, O., Stolper, E.M., 2011. Monte Carlo simulations of metasomatic enrichment in the lithosphere and implications for the source of alkaline basalts. J. Petrol. 52, 1415-1442. https://doi.org/10.1093/petrology/egr007.

Plank, T., Langmuir, C.H., 1998. The chemical composition of subducting sediment and its consequences for the crust and mantle. Chem. Geol. 145 (3-4), 325-394. https:// doi.org/10.1016/S0009-2541(97)00150-2.

Price, R.C., Kennedy, A.K., Riggs-Sneeringer, M., Frey, F.A., 1986. Geochemistry of basalts from the Indian Ocean Triple junction: implications for the generation and evolution of Indian Ocean ridge basalts. Earth Planet. Sci. Lett. 78, 379-396. https:// doi.org/10.1016/0012-821X(86)90005-1.

Qian, S.P., Ren, Z.Y., Richard, W., Zhang, L., Zhang, Y.H., Hong, L.B., Ding, X.L., Wu, Y.D., 2017. Petrogenesis of Early Cretaceous basaltic lavas from the North China Craton: Implications for cratonic destruction. J. Geophys. Res. Solid Earth 122 (3), 1900-1918. https://doi.org/10.1002/2016JB013548.

Rehkämper, M., Hofmann, A.W., 1997. Recycled ocean crust and sediment in Indian Ocean MORB. Earth Planet. Sci. Lett. 147 (1-4), 93-106. https://doi.org/10.1016/ S0012-821X(97)00009-5.

Ren, Z.Y., Ingle, S., Takahashi, E., Hirano, N., Hirata, T., 2005. The chemical structure of the Hawaiian mantle plume. Nature 436, 837-840. https://doi.org/10.1038/ nature03907.

Ren, Z.Y., Wu, Y.D., Zhang, L., Nichols, A.R.L., Hong, L.B., Zhang, Y.H., Zhang, Y., Liu, J.Q., Xi, Y.G., 2017. Primary magmas and mantle sources of Emeishan basalts constrained from major element, trace element and $\mathrm{Pb}$ isotope compositions of olivinehosted melt inclusions. Geochim. Cosmochim. Acta 208, 63-85. https://doi.org/10. 1016/j.gca.2017.01.054.

Roedder, E., 1979. Origin and significance of magmatic inclusions. Bull. Mineral. 102, 487-510. https://doi.org/10.3406/bulmi.1979.7299.

Rudnick, R.L., Gao, S., 2003. Composition of the continental crust. Treatise on. Geochemistry 3, 1-64. https://doi.org/10.1016/B0-08-043751-6/03016-4.

Saal, A.E., Hart, S.R., Shimizu, N., Hauri, E.H., Layne, G.D., 1998. Pb isotopic variability in melt inclusions from oceanic island basalts. Polynesia. Science 282, 1481-1484. https://doi.org/10.1126/science.282.5393.1481.

Saal, A.E., Hart, S.R., Shimizu, N., Hauri, E.H., Layne, G.D., Eiler, J.M., 2005. Pb isotopic variability in melt inclusions from the EMI - EMII - HIMU mantle end-members and the role of the oceanic lithosphere. Earth Planet. Sci. Lett. 240, 605-620. https://doi. org/10.1016/j.epsl.2005.10.002.

Schiano, P., 2003. Primitive mantle magmas recorded as silicate melt inclusions in ig neous minerals. Earth Sci. Rev. 63, 121-144. https://doi.org/10.1016/S0012- 
8252(03)00034-5

Shinjo, R., 1999. Geochemistry of high Mg andesites and the tectonic evolution of the Okinawa Trough-Ryukyu arc system. Chem. Geol. 157 (1), 69-88. https://doi.org/ 10.1016/S0009-2541(98)00199-5.

Shinjo, R., Kato, Y., 2000. Geochemical constraints on the origin of bimodal magmatism at the Okinawa Trough, an incipient back-arc basin. Lithos 54 (3-4), 117-137. https://doi.org/10.1016/S0024-4937(00)00034-7.

Shinjo, R., Chung, S.L., Kato, Y., Kimura, M., 1999. Geochemical and Sr-Nd isotopic characteristics of volcanic rocks from the Okinawa Trough and Ryukyu Arc: implications for the evolution of a young, intracontinental back arc basin. J. Geophys. Res. Solid Earth 104 (B5), 10591-10608. https://doi.org/10.1029/1999JB900040.

Shu, Y., Nielsen, S.G., Zeng, Z., Shinjo, R., Blusztajn, J., Wang, X., Chen, S., 2017. Tracing subducted sediment inputs to the Ryukyu arc-Okinawa Trough system: evidence from thallium isotopes. Geochim. Cosmochim. Acta 217, 462-491. https://doi.org/10. 1016/j.gca.2017.08.035.

Sibuet, J.C., Hsu, S.K., Shyu, C.T., Liu, C.S., 1995. Structural and kinematic evolutions of the Okinawa Trough backarc basin. In: Taylor, B. (Ed.), Backarc Basins: Tectonics and Magmatism. Plenum Press, New York, pp. 343-379. https://doi.org/10.1007/978-14615-1843-3 9.

Singer, B.S., Jicha, B.R., Leeman, W.P., Rogers, N.W., Thirlwall, M.F., Ryan, J., Nicolaysen, K.E., 2007. Along-strike trace element and isotopic variation in Aleutian Island arc basalt: subduction melts sediments and dehydrates serpentine. J. Geophys. Res. Solid Earth 112, 623-626. https://doi.org/10.1029/2006JB004897.

Sobolev, A.V., 1996. Melt inclusions in minerals as a source of principle petrological information. Petrology 4, 209-220.

Sobolev, A.V., Hofmann, A.W., Nikogosian, I.K., 2000. Recycled oceanic crust observed in 'ghost plagioclase' within the source of Mauna Loa lavas. Nature 404, 986-990. https://doi.org/10.1038/35010098.

Sorby, H.C., 1858. On the microscopical, structure of crystals, indicating the origin of minerals and rocks. Q. J. Geol. Soc. 14, 453-500. https://doi.org/10.1144/GSL.JGS. 1858.014.01-02.44.

Storey, M., Saunders, A.D., Tarney, J., Gibson, I.L., Norry, M.J., Thirlwall, M.F., Leat, P., Thompson, R.N., Menzies, M.A., 1989. Contamination of Indian Ocean asthenosphere by the Kerguelen-heard mantle plume. Nature 338, 574-576. https://doi.org/10. $1038 / 338574 \mathrm{a} 0$.

Straub, S.M., Layne, G.D., Schmidt, A., Langmuir, C.H., 2004. Volcanic glasses at the Izu arc volcanic front: new perspectives on fluid and sediment melt recycling in subduction zones. Geochem. Geophys. Geosyst. 5 (1), Q01007. https://doi.org/10.1029/ 2002 GC000408.

Streck, M.J., Wacaster, S., 2006. Plagioclase and pyroxene hosted melt inclusions in basaltic andesites of the current eruption of Arenal volcano, Costa Rica. J. Volcanol. Geotherm. Res. 157 (1-3), 236-253. https://doi.org/10.1016/j.jvolgeores.2006.03. 040.

Sun, S.S., 1980. Lead isotopic study of young volcanic rocks from mid-ocean ridges, ocean islands and island arcs. Phil. Trans. R. Soc. Lond., A. 297, 409-445. https://doi.org/ 10.1098/rsta.1980.0224.

Sun, S.S., McDonough, W., 1989. Chemical and isotopic systematics of oceanic basalts: implications for mantle composition and processes. Geol. Soc. Lond., Spec. Publ. 42, 313-345. https://doi.org/10.1144/GSL.SP.1989.042.01.19.

Sun, W., Bennett, V.C., Kamenetsky, V.S., 2004. The mechanism of Re enrichment in arc magmas: evidence from Lau Basin basaltic glasses and primitive melt inclusions. Earth Planet. Sci. Lett. 222 (1), 101-114. https://doi.org/10.1016/j.epsl.2004.02. 011.

Tatsumoto, M., 1978. Isotopic composition of lead in oceanic basalt and its implication to mantle evolution. Earth Planet. Sci. Lett. 38, 63-87. https://doi.org/10.1016/0012821X(78)90126-7.

Thirlwall, M.F., 1997. $\mathrm{Pb}$ isotopic and elemental evidence for OIB derivation from young HIMU mantle. Chem. Geol. 139, 51-74. https://doi.org/10.1016/S0009-2541(97) 00033-8.

Tolstykh, M.L., Naumov, V.B., Gavrilenko, M.G., Ozerov, A.Y., Kononkova, N.N., 2012. Chemical composition, volatile components, and trace elements in the melts of the
Gorely volcanic center, southern Kamchatka: evidence from inclusions in minerals. Geochem. Int. 50 (6), 522-550. https://doi.org/10.1134/S0016702912060079.

Wang, K.L., Chung, S.L., O'Reilly, S.Y., Sun, S.S., Shinjo, R., Chen, C.H., 2004. Geochemical constraints for the genesis of post-collisional magmatism and the geodynamic evolution of the northern Taiwan region. J. Petrol. 45, 975-1011. https:// doi.org/10.1093/petrology/egh001.

Weaver, B.L., 1991. The origin of ocean island basalt end-member compositions: trace element and isotopic constraints. Earth Planet. Sci. Lett. 104, 381-397. https://doi. org/10.1016/0012-821X(91)90217-6.

Weis, D., Kieffer, B., Maerschalk, C., Barling, J., Jong, J.D., Williams, G.A., Hanano, D., Pretorius, W., Mattielli, N., Scoates, J., Goolaerts, A., Friedman, R., Mahoney, J.B., 2006. High-precision isotopic characterization of USGS reference materials by TIMS and MC-ICP-MS. Geochem. Geophys. Geosyst. 7, Q08006. https://doi.org/10.1029/ 2006GC001283.

Wen, L., 2006. A compositional anomaly at the Earth's core-mantle boundary as an anchor to the relatively slowly moving surface hotspots and as source to the DUPAL anomaly. Earth Planet. Sci. Lett. 246 (1-2), 138-148. https://doi.org/10.1016/j.epsl. 2006.04.024.

White, W.M., Duncan, R.A., 1996. Geochemistry and Geochronology of the Society Islands: New Evidence for Deep Mantle Recycling. https://doi.org/10.1029/ GM095p0183.

White, W.M., Hofmann, A.W., Puchelt, H., 1987. Isotope geochemistry of Pacific midocean ridge basalt. J. Geophys. Res. 92, 4881-4893. https://doi.org/10.1029/ JB092iB06p04881.

Willbold, M., Stracke, A., 2010. Formation of enriched mantle components by recycling of upper and lower continental crust. Chem. Geol. 276, 188-197. https://doi.org/10 1016/j.chemgeo.2010.06.005

Yan, Q.S., Shi, X.F., 2014. Petrologic perspectives on tectonic evolution of a nascent basin (Okinawa Trough) behind Ryukyu Arc: a review. Acta Oceanol. Sin. 33 (4), 1-12. https://doi.org/10.1007/s13131-014-0400-2.

Yu, Z., Zhai, S., Guo, K., Zhou, Y., Zong, T., 2016. Helium isotopes in volcanic rocks from the Okinawa Trough-impact of volatile recycling and crustal contamination. Geol. J. 51 (S1), 376-386. https://doi.org/10.1002/gj.2794.

Zajacz, Z., Halter, W., 2007. LA-ICPMS analyses of silicate meltinclusions in co-precipitated minerals: Quantification, data analysis and mineral/melt partitioning. Geochim. Cosmochim. Acta 71, 1021-1040. https://doi.org/10.1016/j.gca.2006.11. 001.

Zeng, Z., Yu, S., Wang, X., Fu, Y., Yin, X., Zhang, G., Wang, X., Chen, S., 2010. Geochemical and isotopic characteristics of volcanic rocks from the northern East China Sea shelf margin and the Okinawa Trough. Acta Oceanol. Sin. 29 (4), 48-61. https://doi.org/10.1007/s13131-010-0050-y.

Zhang, L., Ren, Z.Y., Nichols, A.R.L., Zhang, Y.H., Qian, S.P., Liu, J.Q., 2014. Lead isotope analysis of melt inclusions by LA-MC-ICP-MS. J. Anal. Atom. Spectromet. 29, 1393-1405. https://doi.org/10.1039/C4JA00088A.

Zhang, Y.H., Ren, Z.Y., Hong, L.B., Zhang, L., Huang, X.L., Chen, L.L., 2016. Petrogenesis of Cenozoic Wangjiadashan basalts in Changle area, Shandong Province. Geochimica 45 (1), 1-23. https://doi.org/10.19700/j.0379-1726.2016.01.001.

Zhang, G.L., Chen, L.H., Jackson, M.G., Hofmann, A.W., 2017. Evolution of carbonated melt to alkali basalt in the South China Sea. Nat. Geosci. 10 (3), 229. https://doi-org443.webvpn.las.ac.cn/10.1038/ngeo2877.

Zhang, Y., Zeng, Z., Li, X., Yin, X., Wang, X., Chen, S., 2018. High-potassium volcanic rocks from the Okinawa Trough: Implications for a cryptic potassium-rich and DUPAL-like source. Geol. J. 53 (5), 1755-1766. https://doi.org/10.1002/gj.3000.

Zhang, L., Ren, Z.Y., Xia, X.P., Yang, Q., Hong, L.B., Wu, D., 2019. In situ determination of trace elements in melt inclusions using laser ablation-inductively coupled plasmasector field-mass spectrometry. Rapid Commun. Mass Spectrom. 33, 361-370.

Zheng, Y.F., 2012. Metamorphic chemical geodynamics in continental subduction zones. Chem. Geol. 328, 5-48. https://doi.org/10.1016/j.chemgeo.2012.02.005.

Zindler, A., Hart, S., 1986. Chemical geodynamics. Annu. Rev. Earth Planet. Sci. 14, 493-495. https://doi.org/10.1146/annurev.ea.14.050186.002425. 